\title{
Article \\ Neuronal Modulators from the Coral-Associated Fungi Aspergillus candidus
}

\author{
Gao-Yang Peng 1,2,3, Tibor Kurtán ${ }^{4} \mathbb{D}$, Attila Mándi ${ }^{4} \mathbb{D}$, Jing He ${ }^{5}$, Zheng-Yu Cao ${ }^{5}$ (D) Hua Tang ${ }^{6}$, \\ Shui-Chun Mao ${ }^{1, *}$ and Wen Zhang ${ }^{2,3, *}$
}

1 School of Pharmacy, Nanchang University, 461 Bayi Road, Nanchang 330006, China; penggaoyang42@163.com

2 School of Medicine, Tongji University, 1239 Si-Ping Road, Shanghai 200092, China

3 School of Pharmacy, Navy Medical University, 325 Guo-He Rd., Shanghai 200433, China

4 Department of Organic Chemistry, University of Debrecen, POB 400, H-4002 Debrecen, Hungary; kurtan.tibor@science.unideb.hu (T.K.); mandi.attila@science.unideb.hu (A.M.)

5 State Key Laboratory of Natural Medicines, Department of TCM Pharmacology, School of Traditional Chinese Pharmacy, China Pharmaceutical University, 639 Long-Mian Ave., Nanjing 211198, China; 18796219566@163.com (J.H.); zycao1999@hotmail.com (Z.-Y.C.)

6 Institute of Translational Medicine, Shanghai University, 99 Shang-Da Road, Shanghai 200444, China; tanghua0309@126.com

* Correspondence: maoshuichun@ncu.edu.cn (S.-C.M.); wenzhang1968@163.com (W.Z.)

Citation: Peng, G.-Y.; Kurtán, T.; Mándi, A.; He, J.; Cao, Z.-Y.; Tang, H.; Mao, S.-C.; Zhang, W. Neuronal Modulators from the Coral-Associated Fungi Aspergillus candidus. Mar. Drugs 2021, 19, 281. https://doi.org/10.3390/md 19050281

Academic Editor: Rob Keyzers

Received: 21 April 2021

Accepted: 13 May 2021

Published: 19 May 2021

Publisher's Note: MDPI stays neutral with regard to jurisdictional claims in published maps and institutional affiliations.

\begin{abstract}
Three new p-terphenyl derivatives, named $4^{\prime \prime}$-O-methyl-prenylterphenyllin B (1) and phenylcandilide A and B (17 and 18), and three new indole-diterpene alkaloids, asperindoles E-G (22-24), were isolated together with eighteen known analogues from the fungi Aspergillus candidus associated with the South China Sea gorgonian Junceela fragillis. The structures and absolute configurations of the new compounds were elucidated on the basis of spectroscopic analysis, and DFT/NMR and TDDFT/ECD calculations. In a primary cultured cortical neuronal network, the compounds $6,9,14,17,18$ and 24 modulated spontaneous $\mathrm{Ca}^{2+}$ oscillations and 4-aminopyridine hyperexcited neuronal activity. A preliminary structure-activity relationship was discussed.
\end{abstract}

Keywords: coral-associated fungi; secondary metabolites; $p$-terphenyl; indole-diterpene alkaloids; spontaneous $\mathrm{Ca}^{2+}$ oscillations

\section{Introduction}

Fungi of Aspergillus candidus is found to be wide-spread in soil [1] and marine environments [2-4], and also co-existing with various animals and plants [5-8]. The fungi are reported to produce prolific secondary metabolites, including $p$-terphenyls [9-11], terpenes [3], flavonoids [7,12,13], cyclopeptides [6], alkaloids [5], polyketones, and fatty acids [3]. These metabolites display a wide spectrum of biological activities, including cytotoxic [5,8], antibacterial [5,6], antifungal [3,8], antioxidant [6], and immunosuppressive activities [14].

As part of our continuing search for bioactive molecules from marine invertebrates and the associated fungi [15-17], a strain of $A$. candidus was isolated from the internal tissues of the gorgonian coral Junceela fragillis, collected from the Xisha area of the South China Sea. Chemical investigation of the fermentation extract of this fungus resulted in the isolation of three new $p$-terphenyl derivatives and three new indole-diterpene alkaloids, together with eighteen known analogues. Further, $p$-Terphenyls are regarded as the main metabolites of $A$. candidus. More than 230 analogues have been reported up to date, with the chemical diversity being attributed to the substituents on rings A and $C[8,18,19]$. The indole-diterpene alkaloids are a cluster of characteristic metabolites from this genus and were firstly reported from the titled fungi [20]. These metabolites are structurally constructed with an indole molecule and a saculatane diterpenoid. The biosynthetic process 
of both types of metabolites were conducted by investigating $6^{\prime}$-hydroxy-4, $2^{\prime}, 3^{\prime}, 4^{\prime \prime}$-tetramethoxy-p-terphenyl $[18,19,21]$ for $p$-terphenyls, and penitrem [22] and lolitrems [23,24] for the indole-diterpene alkaloids. The bioactivities and the intriguing ring-systems of these molecules also attracted attention for total synthesis $[19,25,26]$. Herein, we report the isolation, structure elucidation, and neuronal modulatory activity of these compounds.

\section{Results}

The $A$. candidus was cultivated on biomalt agar medium and then extracted with EtOAc. The EtOAc extract was subjected to the usual workup for isolation $[15,16,27]$ to yield compounds 1-24 (Figure 1), including eighteen $p$-terphenyl derivatives and six indole-diterpene alkaloids. Based on the spectroscopic analysis and comparison with the reported data, the known compounds were determined as $3^{\prime \prime}$-hydroxyl-prenylterphenyllin (2), 3-methoxy-4"-deoxyterprenin (3), 3-hydroxyterphenyllin (4) [28], 4-O-methylprenylterphenyllin (5) [9], terphenyllin (6) [12,28], 3-methoxyterprenin (7) [14], prenylterphenyllin J (8) [8], 3,3'-dihydroxy-6'-desmethyl terphenyllin (9) [29], deoxyterhenyllin (10) [30], prenylterphenyllin (11) [4], prenylterphenyllin B (12) [11], candidusins A (13) and B (14) [31], prenylcandidusin A (15) [11], 4-methyl-candidusin A (16) [32], and asperindoles A (19), C (20) and D (21) [20]. A complete NMR assignment is presented for the compounds 2 and 3 since there is no report for the NMR data of both the compounds. The assignments are fully supported by those of co-occurring prenylterphenyllin (11) [4] and 3-methoxyterprenin (7) [14], two analogues once reported from the soil-derived strains of the same species.

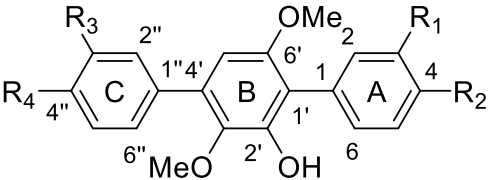

$1 \mathrm{R}_{1}=\mathrm{H}, \mathrm{R}_{2}=\mathrm{OH}, \mathrm{R}_{3}=\mathrm{X}, \mathrm{R}_{4}=\mathrm{OMe}$

$2 \mathrm{R}_{1}=\mathrm{X}, \mathrm{R}_{2}=\mathrm{R}_{3}=\mathrm{R}_{4}=\mathrm{OH}$

$3 \mathrm{R}_{1}=\mathrm{OMe}, \mathrm{R}_{2}=\mathrm{OX}, \mathrm{R}_{3}=\mathrm{R}_{4}=\mathrm{H}$

$4 \mathrm{R}_{1}=\mathrm{R}_{2}=\mathrm{R}_{4}=\mathrm{OH}, \mathrm{R}_{3}=\mathrm{H}$

$5 \mathrm{R}_{1}=\mathrm{X}, \mathrm{R}_{2}=\mathrm{OMe}, \mathrm{R}_{3}=\mathrm{H}, \mathrm{R}_{4}=\mathrm{OH}$

$6 \mathrm{R}_{1}=\mathrm{R}_{3}=\mathrm{H}, \mathrm{R}_{2}=\mathrm{R}_{4}=\mathrm{OH}$

$7 \mathrm{R}_{1}=\mathrm{OMe}, \mathrm{R}_{2}=\mathrm{OX}, \mathrm{R}_{3}=\mathrm{H}, \mathrm{R}_{4}=\mathrm{OH}$

$8 \mathrm{R}_{1}=\mathrm{R}_{2}=\mathrm{OMe}, \mathrm{R}_{3}=\mathrm{X}, \mathrm{R}_{4}=\mathrm{OH}$

$9 \mathrm{R}_{1}=\mathrm{R}_{2}=\mathrm{R}_{3}=\mathrm{R}_{4}=\mathrm{OH}$

$10 R_{1}=R_{3}=R_{4}=H, R_{2}=O H$

$11 \mathrm{R}_{1}=X, \mathrm{R}_{2}=\mathrm{R}_{4}=\mathrm{OH}, \mathrm{R}_{3}=\mathrm{H}$

$12 R_{1}=H, R_{2}=R_{4}=O H, R_{3}=X$

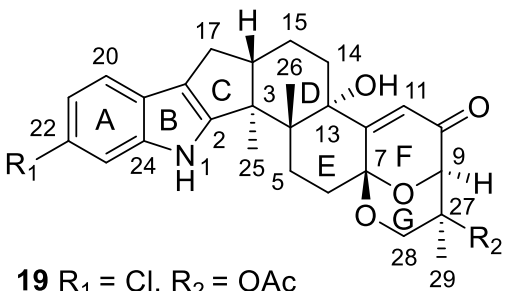

$20 R_{1}=\mathrm{Cl}, \mathrm{R}_{2}=\mathrm{Y}, \mathrm{R}=\mathrm{OAC}$

$21 R_{1}=H, R_{2}=Y, R=O A C$

$22 \mathrm{R}_{1}=\mathrm{H}, \mathrm{R}_{2}=\mathrm{OH}$

$23 \mathrm{R}_{1}=\mathrm{Cl}, \mathrm{R}_{2}=\mathrm{Y}, \mathrm{R}=\mathrm{OH}$

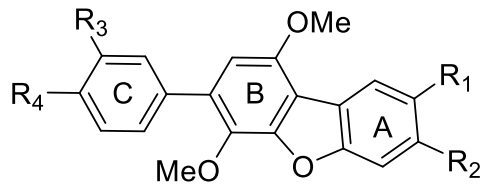

$13 \mathrm{R}_{1}=\mathrm{R}_{2}=\mathrm{R}_{4}=\mathrm{OH}, \mathrm{R}_{3}=\mathrm{H}$

$14 \mathrm{R}_{1}=\mathrm{R}_{2}=\mathrm{R}_{3}=\mathrm{R}_{4}=\mathrm{OH}$

$15 \mathrm{R}_{1}=\mathrm{R}_{2}=\mathrm{R}_{4}=\mathrm{OH}, \mathrm{R}_{3}=X$

$16 \mathrm{R}_{1}=\mathrm{R}_{4}=\mathrm{OH}, \mathrm{R}_{2}=\mathrm{OMe}, \mathrm{R}_{3}=\mathrm{H}$

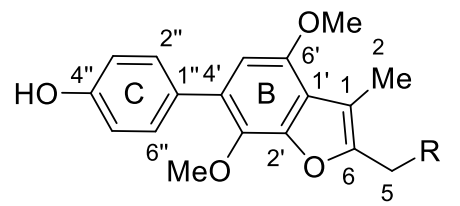

$17 \mathrm{R}=\mathrm{OH}$

$18 \mathrm{R}=\mathrm{COOMe}$
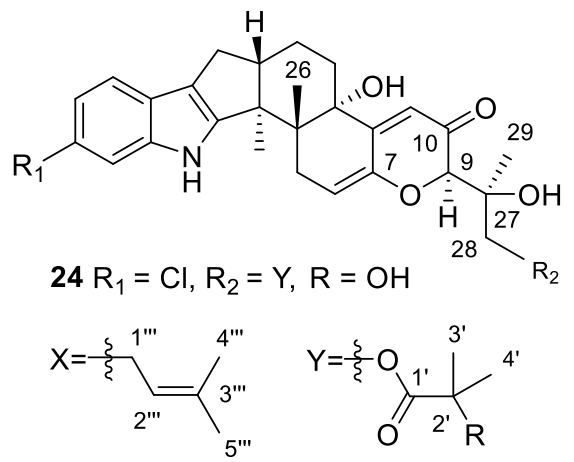

Figure 1. Structures of compounds 1-24. 
Further, $4^{\prime \prime}$-O-methyl-prenylterphenyllin B (1) was obtained as a colorless amorphous solid. Its molecular formula was determined as $\mathrm{C}_{26} \mathrm{H}_{28} \mathrm{O}_{5}$ by HRESIMS, requiring 13 degrees of unsaturation. The IR spectrum displayed absorptions for hydroxy $\left(3357 \mathrm{~cm}^{-1}\right)$ and substituted benzol $\left(1609,1462,834\right.$, and $\left.815 \mathrm{~cm}^{-1}\right)$ functionalities. The presence of benzol rings was supported by the strong UV absorptions at 276, 248, and $209 \mathrm{~nm}$. The NMR spectra of 1 displayed resonances for twenty $s p^{2}$ carbons and six $s p^{3}$ carbons, taking into account the ten degrees of unsaturation. The remaining three degrees of unsaturation assigned to the ring system of this molecule were in agreement with that of the terphenyl framework. Its NMR data were almost identical to those of the co-isolated prenylterphenyllin $\mathrm{B}$ (12) [11], except for the appearance of an additional methoxy group $\left(\delta_{\mathrm{H}} 3.89,3 \mathrm{H}, \mathrm{s} ; \delta_{\mathrm{C}} 55.6, \mathrm{CH}_{3}\right)$. The methoxy group was assigned as $4^{\prime \prime}$-OMe via its HMBC correlations to C- $4^{\prime \prime}$, and further confirmed by its NOE correlation with $\mathrm{H}-5^{\prime \prime}$ (Figure S1). The structure of compound $\mathbf{1}$ was therefore determined as $4^{\prime \prime}$-O-methyl-prenylterphenyllin B.

Phenylcandilide A (17), obtained as a yellow amorphous solid, had a molecular formula of $\mathrm{C}_{18} \mathrm{H}_{18} \mathrm{O}_{5}$ as deduced from the HRESIMS, indicating 10 degrees of unsaturation. The NMR data of 17 showed similarity to those of 4-methyl-candidusin A (16) [32], regarding the signals for the phenol ring $C$ and benzofuran ring $B$. The $C-2$ to $C-5$ diene fragment of the phenol ring $\mathrm{A}$ in 16, however, was degraded to a methyl and a hydroxymethyl groups in 17. The distinct $\mathrm{HMBC}$ correlations from $\mathrm{H}_{3}-2$ to $\mathrm{C}-1^{\prime}$ and $\mathrm{C}-6$, and $\mathrm{H}_{2}-5$ to $\mathrm{C}-6$ and $\mathrm{C}-1$ confirmed the location of 1-Me and 6- $\mathrm{CH}_{2} \mathrm{OH}$ (Figure 2). The structure of $\mathbf{1 7}$ was determined and nominated as phenylcandilide $\mathrm{A}$.

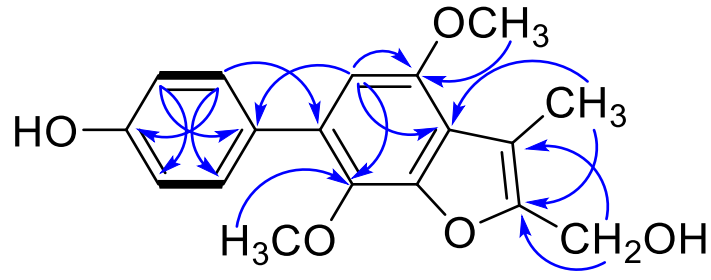

17

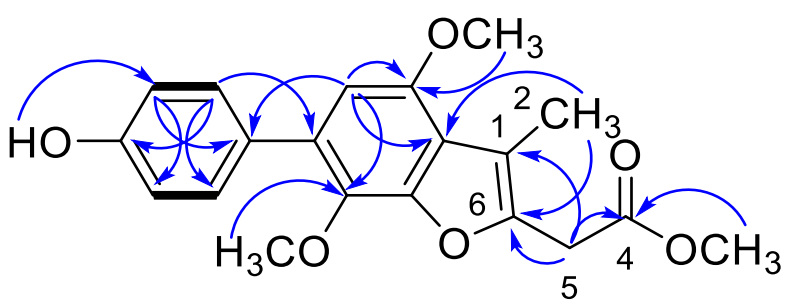

18
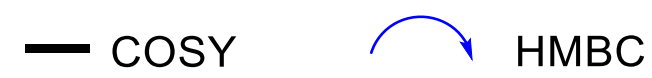

Figure 2. Selected COSY and HMBC correlations of compounds $\mathbf{1 7}$ and $\mathbf{1 8 .}$

Phenylcandilide B (18) was obtained as a yellow amorphous solid. Its molecular formula was established as $\mathrm{C}_{20} \mathrm{H}_{20} \mathrm{O}_{6}$ on the basis of the HRESIMS. Comparison of its NMR data (Table 1) with those of $\mathbf{1 7}$ revealed a similarity in the structures. A difference was recognized for the signals of the hydroxymethyl group in $\mathbf{1 7}$ being replaced by a methyl acetate subunit in 18, confirmed by the IR at $1740 \mathrm{~cm}^{-1}$. The location of the methyl acetate subunit was indicated by the diagnostic HMBC correlations from $\mathrm{H}_{2}-5$ to $\mathrm{C}-4, \mathrm{C}-1$ and $\mathrm{C}-6$, and 4-OMe to C-4 (Figure 2). The structure of compound $\mathbf{1 8}$ was thus determined and nominated as phenylcandilide $\mathrm{B}$. 
Table 1. ${ }^{1} \mathrm{H}$ and ${ }^{13} \mathrm{C}$ NMR data for $\mathbf{1}, 17$ and 18.

\begin{tabular}{|c|c|c|c|c|c|c|}
\hline \multirow{2}{*}{ Position } & \multicolumn{2}{|c|}{$1\left(\right.$ in $\left.\mathrm{CDCl}_{3}\right)$} & \multicolumn{2}{|c|}{17 (in DMSO) } & \multicolumn{2}{|c|}{18 (in DMSO) } \\
\hline & $\delta_{\mathrm{H}}{ }^{\mathrm{a}}(J$ in $\mathrm{Hz})$ & $\delta_{\mathrm{C}}{ }^{\mathrm{b}}$, Type & $\delta_{\mathrm{H}}^{\mathrm{c}}(J$ in $\mathrm{Hz})$ & $\delta_{\mathrm{C}}^{\mathrm{b}}$, Type & $\delta_{\mathrm{H}}{ }^{\mathrm{a}}(J$ in $\mathrm{Hz})$ & $\delta_{\mathrm{C}} \mathrm{b}$, Type \\
\hline 1 & & $125.7, \mathrm{C}$ & & 111.7, C & & $112.6, \mathrm{C}$ \\
\hline 2 & $7.36, \mathrm{~d}(8.5)$ & $132.2, \mathrm{CH}$ & $2.30, \mathrm{~s}$ & $9.5, \mathrm{CH}_{3}$ & $2.25, \mathrm{~s}$ & $9.4, \mathrm{CH}_{3}$ \\
\hline 3 & $6.92, \mathrm{~d}(8.5)$ & $115.2, \mathrm{CH}$ & & & & \\
\hline 4 & & $154.8, \mathrm{C}$ & & & & $169.4, \mathrm{C}$ \\
\hline 5 & $6.92, \mathrm{~d}(8.5)$ & $115.2, \mathrm{CH}$ & $4.51, \mathrm{~d}(5.7)$ & $53.5, \mathrm{CH}_{2}$ & $3.93, \mathrm{~s}$ & $31.6, \mathrm{CH}_{2}$ \\
\hline 6 & $7.36, \mathrm{~d}(8.5)$ & $132.2, \mathrm{CH}$ & & $152.2, \mathrm{C}$ & & $145.8, \mathrm{C}$ \\
\hline $1^{\prime}$ & & $116.1, \mathrm{C}$ & & $119.1, \mathrm{C}$ & & $119.0, \mathrm{C}$ \\
\hline $2^{\prime}$ & & 147.3, C & & $146.9, \mathrm{C}$ & & $146.9, \mathrm{C}$ \\
\hline $3^{\prime}$ & & $138.9, \mathrm{C}$ & & $135.9, \mathrm{C}$ & & $135.7, \mathrm{C}$ \\
\hline $4^{\prime}$ & & $132.8, \mathrm{C}$ & & $129.0, \mathrm{C}$ & & $128.9, \mathrm{C}$ \\
\hline $5^{\prime}$ & $6.46, \mathrm{~s}$ & 104.0, CH & $6.57, \mathrm{~s}$ & $105.0, \mathrm{CH}$ & $6.58, \mathrm{~s}$ & $105.2, \mathrm{CH}$ \\
\hline $6^{\prime}$ & & $153.5, \mathrm{C}$ & & $149.6, \mathrm{C}$ & & 149.3, C \\
\hline $1^{\prime \prime}$ & & $130.3, \mathrm{C}$ & & 128.6, C & & $128.6, \mathrm{C}$ \\
\hline $2^{\prime \prime}$ & $7.44, \mathrm{~d}(2.5)$ & $130.0, \mathrm{CH}$ & $7.38, \mathrm{~d}(8.7)$ & $130.3, \mathrm{CH}$ & $7.37, \mathrm{~d}(8.5)$ & $130.3, \mathrm{CH}$ \\
\hline $3^{\prime \prime}$ & & $130.2, \mathrm{C}$ & $6.83, \mathrm{~d}(8.7)$ & $115.0, \mathrm{CH}$ & $6.83, \mathrm{~d}(8.5)$ & 115.0, $\mathrm{CH}$ \\
\hline $4^{\prime \prime}$ & & 157.0, C & & $156.5, \mathrm{C}$ & & $156.5, \mathrm{C}$ \\
\hline $5^{\prime \prime}$ & $6.93, \mathrm{~d}(8.7)$ & $110.3, \mathrm{CH}$ & $6.83, \mathrm{~d}(8.7)$ & $115.0, \mathrm{CH}$ & $6.83, \mathrm{~d}(8.5)$ & $115.0, \mathrm{CH}$ \\
\hline $6^{\prime \prime}$ & 7.45, dd $(8.7,2.5)$ & 127.2, $\mathrm{CH}$ & $7.38, \mathrm{~d}(8.7)$ & $130.3, \mathrm{CH}$ & 7.37, d (8.5) & $130.3, \mathrm{CH}$ \\
\hline $1^{\prime \prime \prime}$ & $3.38, \mathrm{~d}(7.5)$ & 28.7, $\mathrm{CH}_{2}$ & & & & \\
\hline $2^{\prime \prime \prime}$ & $5.36, \mathrm{t}(7.5)$ & $122.5, \mathrm{CH}$ & & & & \\
\hline $3^{\prime \prime \prime}$ & & 132.8, C & & & & \\
\hline $4^{\prime \prime \prime}$ & $1.73, \mathrm{~s}$ & $18.0, \mathrm{CH}_{3}$ & & & & \\
\hline $5^{\prime \prime \prime}$ & $1.75, \mathrm{~s}$ & 26.0, $\mathrm{CH}_{3}$ & & & & \\
\hline 4-OMe & & & & & $3.66, \mathrm{~s}$ & $52.1, \mathrm{CH}_{3}$ \\
\hline $3^{\prime}-\mathrm{OMe}$ & $3.45, \mathrm{~s}$ & $60.8, \mathrm{CH}_{3}$ & $3.71, \mathrm{~s}$ & $60.4, \mathrm{CH}_{3}$ & $3.68, \mathrm{~s}$ & $60.3, \mathrm{CH}_{3}$ \\
\hline $6^{\prime}-\mathrm{OMe}$ & $3.74, \mathrm{~s}$ & $56.1, \mathrm{CH}_{3}$ & $3.85, \mathrm{~s}$ & $55.7, \mathrm{CH}_{3}$ & $3.85, \mathrm{~s}$ & $55.7, \mathrm{CH}_{3}$ \\
\hline $4^{\prime \prime}-\mathrm{OMe}$ & $3.89, \mathrm{~s}$ & $55.6, \mathrm{CH}_{3}$ & & & & \\
\hline 5-OH & & & $5.28, \mathrm{t}(5.7)$ & & & \\
\hline $2^{\prime}-\mathrm{OH}$ & $5.94, \mathrm{~s}$ & & & & & \\
\hline $4^{\prime \prime}-\mathrm{OH}$ & & & $9.51, \mathrm{~s}$ & & $9.48, \mathrm{~s}$ & \\
\hline
\end{tabular}

${ }^{\mathrm{a}} 500 \mathrm{MHz} .{ }^{\mathrm{b}} 125 \mathrm{MHz} .{ }^{\mathrm{c}} 600 \mathrm{MHz}$.

Asperindole E (22) was obtained as an optically active, white powder. Its molecular formula was established as $\mathrm{C}_{27} \mathrm{H}_{31} \mathrm{NO}_{5}$ by HRESIMS, implying 13 degrees of unsaturation. The IR spectrum of 22 displayed absorptions for hydroxy $\left(3360 \mathrm{~cm}^{-1}\right)$ and substituted benzol $\left(1632,1468,800\right.$, and $\left.742 \mathrm{~cm}^{-1}\right)$ functionalities. The presence of an $\alpha, \beta$-unsaturated ketone moiety was suggested by the characteristic IR absorption at $1658 \mathrm{~cm}^{-1}$. The strong UV absorptions at 279, 268, 230 and $210 \mathrm{~nm}$ were in agreement with the presence of a benzol ring or an $\alpha, \beta$-unsaturated ketone moiety in the structure. The NMR spectra (Table 2) demonstrated a great similarity to the known metabolites of asperindoles A-D, previously obtained from an ascidian-derived fungus Aspergillus sp. [20], suggesting the same indole-diterpene framework for these molecules. Signals for the acetyl group in asperindole B were not observed for 22. The structure of 22 was suggested to be the deacetyl analogues of asperindole B, which was fully confirmed by 2D NMR experiments, particularly HMBC and NOESY (Figure 3). The absolute configurations of 22 were the same as that of asperindoles A-D on the basis of the similar ECD spectra (Figure 4). The structure of compound 22 was thus determined as asperindole E. 
Table 2. ${ }^{1} \mathrm{H}$ and ${ }^{13} \mathrm{C}$ NMR data for 22-24.

\begin{tabular}{|c|c|c|c|c|c|c|}
\hline \multirow{2}{*}{ Position } & \multicolumn{2}{|c|}{$22\left(\right.$ in $\left.\mathrm{CDCl}_{3}\right)$} & \multicolumn{2}{|c|}{$23\left(\right.$ in $\left.\mathrm{CDCl}_{3}\right)$} & \multicolumn{2}{|c|}{24 (in DMSO) } \\
\hline & $\delta_{\mathrm{H}}{ }^{\mathrm{a}}(J$ in $\mathrm{Hz})$ & $\delta_{\mathrm{C}} \mathrm{b}$, Type & $\delta_{\mathrm{H}}{ }^{\mathrm{c}}(J$ in $\mathrm{Hz})$ & $\delta_{\mathrm{C}}^{\mathrm{b}}$, Type & $\delta_{\mathrm{H}}{ }^{\mathrm{a}}(J$ in $\mathrm{Hz})$ & $\delta_{\mathrm{C}}{ }^{\mathrm{b}}$, Type \\
\hline 1-NH & $7.70, \mathrm{~s}$ & & $7.72, \mathrm{~s}$ & & $10.96, \mathrm{~s}$ & \\
\hline 2 & & 152.0, C & & $152.8, \mathrm{C}$ & & $153.9, \mathrm{C}$ \\
\hline 3 & & $52.0, \mathrm{C}$ & & $52.1, \mathrm{C}$ & & $50.4, \mathrm{C}$ \\
\hline 4 & & $39.4, \mathrm{C}$ & & $39.4, \mathrm{C}$ & & $42.7, \mathrm{C}$ \\
\hline $5 \alpha$ & $\begin{array}{c}1.87, \mathrm{dd} \\
(11.5,9.2)\end{array}$ & 27.3, $\mathrm{CH}_{2}$ & $1.84, \mathrm{ov}^{\mathrm{d}}$ & $27.2, \mathrm{CH}_{2}$ & $\begin{array}{c}2.37, \mathrm{dd} \\
(17.0,6.0)\end{array}$ & $30.6, \mathrm{CH}_{2}$ \\
\hline $5 \beta$ & $2.65, \mathrm{dd}(11.5,9.5)$ & & $2.60, \mathrm{ov}^{\mathrm{d}}$ & & $3.02, \mathrm{~d}(17.0)$ & \\
\hline $6 \alpha$ & $2.23, \mathrm{dd}(13.0,9.2)$ & $31.1, \mathrm{CH}_{2}$ & $2.12, \mathrm{dd}(13.2,9.0)$ & $30.7, \mathrm{CH}_{2}$ & & $111.5, \mathrm{CH}$ \\
\hline $6 \beta$ & 2.66 , dd $(13.0,9.5)$ & & $2.61, \mathrm{ov}^{\mathrm{d}}$ & & $5.69, \mathrm{~m}$ & \\
\hline 7 & & $94.5, \mathrm{C}$ & & $94.0, \mathrm{C}$ & & $145.0, \mathrm{C}$ \\
\hline 9 & $4.05, \mathrm{~d}(2.0)$ & $84.0, \mathrm{CH}$ & $4.81, \mathrm{~d}(2.4)$ & $79.2, \mathrm{CH}$ & $4.25, \mathrm{~d}(1.5)$ & $82.1, \mathrm{CH}$ \\
\hline 10 & & $196.5, \mathrm{C}$ & & 196.0, C & & $194.7, \mathrm{C}$ \\
\hline 11 & $6.24, \mathrm{~s}$ & $120.7, \mathrm{CH}$ & $6.22, \mathrm{~s}$ & $120.4, \mathrm{CH}$ & $5.84, \mathrm{~s}$ & $116.1, \mathrm{CH}$ \\
\hline 12 & & $158.9, \mathrm{C}$ & & $159.8, \mathrm{C}$ & & $154.5, \mathrm{C}$ \\
\hline 13 & & $78.9, \mathrm{C}$ & & $78.8, \mathrm{C}$ & & $73.8, \mathrm{C}$ \\
\hline $14 \alpha$ & $2.00, \mathrm{ov}^{\mathrm{d}}$ & $33.9, \mathrm{CH}_{2}$ & $2.00, \mathrm{ov}^{\mathrm{d}}$ & $33.8, \mathrm{CH}_{2}$ & $1.93, \mathrm{ov}^{\mathrm{d}}$ & $31.7, \mathrm{CH}_{2}$ \\
\hline $14 \beta$ & $1.97, \mathrm{ov}^{\mathrm{d}}$ & & $1.96, \mathrm{dd}(13.2,4.8)$ & & $1.83, \mathrm{ov}^{\mathrm{d}}$ & \\
\hline $15 \alpha$ & $2.08, \mathrm{dd}(13.0,4.0)$ & 21.3, $\mathrm{CH}_{2}$ & 2.09, ov $^{\mathrm{d}}$ & $21.3, \mathrm{CH}_{2}$ & $1.92, \mathrm{ov}^{\mathrm{d}}$ & $21.1, \mathrm{CH}_{2}$ \\
\hline $15 \beta$ & $1.82, \mathrm{~m}$ & & $1.82, \mathrm{ov}^{\mathrm{d}}$ & & $1.66, \mathrm{~m}$ & \\
\hline 16 & $2.83, \mathrm{~m}$ & $48.6, \mathrm{CH}$ & $2.82, \mathrm{~m}$ & $48.7, \mathrm{CH}$ & $2.72, \mathrm{~m}$ & $49.3, \mathrm{CH}$ \\
\hline $17 \alpha$ & $\begin{array}{c}2.45, \mathrm{dd} \\
(13.2,11.0)\end{array}$ & 27.7, $\mathrm{CH}_{2}$ & $\begin{array}{c}2.43, \mathrm{dd} \\
(13.2,10.2)\end{array}$ & $27.7, \mathrm{CH}_{2}$ & $\begin{array}{c}2.33, \mathrm{dd} \\
(13.0,10.5)\end{array}$ & $26.8, \mathrm{CH}_{2}$ \\
\hline $17 \beta$ & $\begin{array}{c}2.74, \mathrm{dd} \\
(13.2,6.5)\end{array}$ & & $\begin{array}{c}2.71, \mathrm{dd} \\
(13.2,6.0)\end{array}$ & & $\begin{array}{c}2.61, \mathrm{dd} \\
(13.0,7.0)\end{array}$ & \\
\hline 18 & & $117.4, \mathrm{C}$ & & $117.5, \mathrm{C}$ & & 115.3, C \\
\hline 19 & & $125.3, \mathrm{C}$ & & $123.9, \mathrm{C}$ & & 123.3, C \\
\hline 20 & $7.43, \mathrm{dd}(6.7,2.0)$ & $118.7, \mathrm{CH}$ & 7.31, d (8.4) & $119.3, \mathrm{CH}$ & $7.28, \mathrm{~d}(8.5)$ & $118.9, \mathrm{CH}$ \\
\hline 21 & $7.08, \operatorname{td}(6.7,2.0)$ & $119.9, \mathrm{CH}$ & $7.04, \mathrm{dd}(8.4,1.8)$ & $120.4, \mathrm{CH}$ & $6.92, \mathrm{dd}(8.5,2.0)$ & $118.8, \mathrm{CH}$ \\
\hline 22 & $7.10, \operatorname{td}(6.7,2.0)$ & $120.7, \mathrm{CH}$ & & $126.4, \mathrm{C}$ & & $123.9, \mathrm{C}$ \\
\hline 23 & $7.31, \mathrm{dd}(6.7,2.0)$ & $111.7, \mathrm{CH}$ & $7.28, \mathrm{~d}(1.8)$ & $111.6, \mathrm{CH}$ & $7.26, \mathrm{~d}(2.0)$ & $111.3, \mathrm{CH}$ \\
\hline 24 & & $139.9, \mathrm{C}$ & & $140.2, \mathrm{C}$ & & $140.3, \mathrm{C}$ \\
\hline 25 & $1.38, \mathrm{~s}$ & $16.4, \mathrm{CH}_{3}$ & $1.37, \mathrm{~s}$ & $16.4, \mathrm{CH}_{3}$ & $1.29, \mathrm{~s}$ & $16.4, \mathrm{CH}_{3}$ \\
\hline 26 & $1.16, \mathrm{~s}$ & $24.5, \mathrm{CH}_{3}$ & $1.14, \mathrm{~s}$ & $24.5, \mathrm{CH}_{3}$ & $0.99, \mathrm{~s}$ & $19.7, \mathrm{CH}_{3}$ \\
\hline 27 & & $66.8, \mathrm{C}$ & & $76.9, \mathrm{C}$ & & $74.3, \mathrm{C}$ \\
\hline $28 \alpha$ & 3.64, dd $(12.0,2.0)$ & $68.2, \mathrm{CH}_{2}$ & $4.21, \mathrm{dd}(13.2,2.4)$ & $65.0, \mathrm{CH}_{2}$ & & $67.9, \mathrm{CH}_{2}$ \\
\hline $28 \beta$ & $3.75, \mathrm{~d}(12.0)$ & & $3.69, \mathrm{~d}(13.2)$ & & $3.88, \mathrm{~s}$ & \\
\hline 29 & $1.07, \mathrm{~s}$ & $18.9, \mathrm{CH}_{3}$ & $1.37, \mathrm{~s}$ & $17.3, \mathrm{CH}_{3}$ & $1.30, \mathrm{~s}$ & $21.9, \mathrm{CH}_{3}$ \\
\hline $1^{\prime}$ & & & & $176.9, \mathrm{C}$ & & $175.5, \mathrm{C}$ \\
\hline $2^{\prime}$ & & & & $72.5, \mathrm{C}$ & & $71.3, \mathrm{C}$ \\
\hline $3^{\prime}$ & & & $1.52, \mathrm{~s}$ & 27.4, $\mathrm{CH}_{3}$ & $1.29, \mathrm{~s}$ & 27.3, $\mathrm{CH}_{3}$ \\
\hline $4^{\prime}$ & & & $1.53, \mathrm{~s}$ & $27.3, \mathrm{CH}_{3}$ & $1.29, \mathrm{~s}$ & $27.3, \mathrm{CH}_{3}$ \\
\hline $13-\mathrm{OH}$ & & & & & $4.98, \mathrm{~s}$ & \\
\hline $27-\mathrm{OH}$ & & & & & $5.06, \mathrm{~d}(1.5)$ & \\
\hline $2^{\prime}-\mathrm{OH}$ & & & & & $5.26, \mathrm{~s}$ & \\
\hline
\end{tabular}

${ }^{a} 500 \mathrm{MHz} .{ }^{\mathrm{b}} 125 \mathrm{MHz} .{ }^{\mathrm{c}} 600 \mathrm{MHz} .{ }^{\mathrm{d}}$ overlapped signals.

Asperindole $\mathrm{F}$ (23), obtained as an optically active, white powder, has a molecular formula of $\mathrm{C}_{31} \mathrm{H}_{36} \mathrm{ClNO}_{7}$ as determined by HRESIMS. The presence of a chlorine atom in the molecule was indicated by the isotopic peaks at $m / z 568 / 570[\mathrm{M}-\mathrm{H}]^{-}$with a ratio of 3:1. The NMR spectra of 23 (Table 2) resembled those of asperindole C (20) [20] (Table S1), except for the acetyl group which is absent, showing the same difference pattern as that between asperindole E (22) and B. Compound $\mathbf{2 3}$ is the deacetylated derivative of asperindole $\mathrm{C}$, and was named as asperindole $\mathrm{F}$. This assignment was further confirmed by NMR and ECD experiments (Figures 3 and 4). 


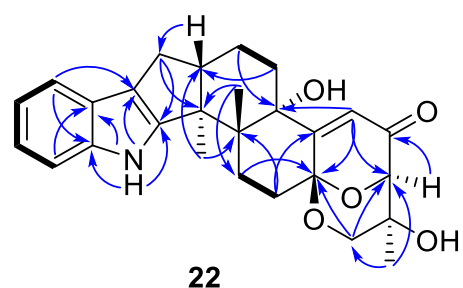

22
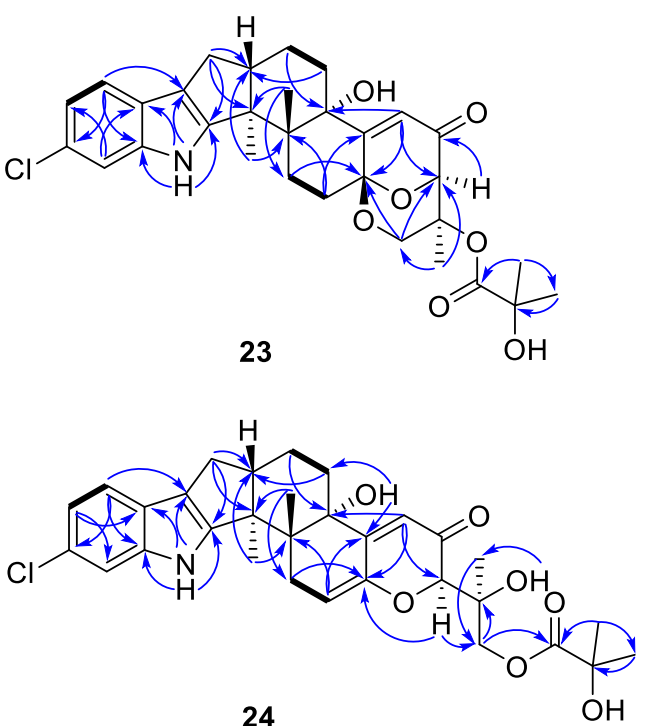

24
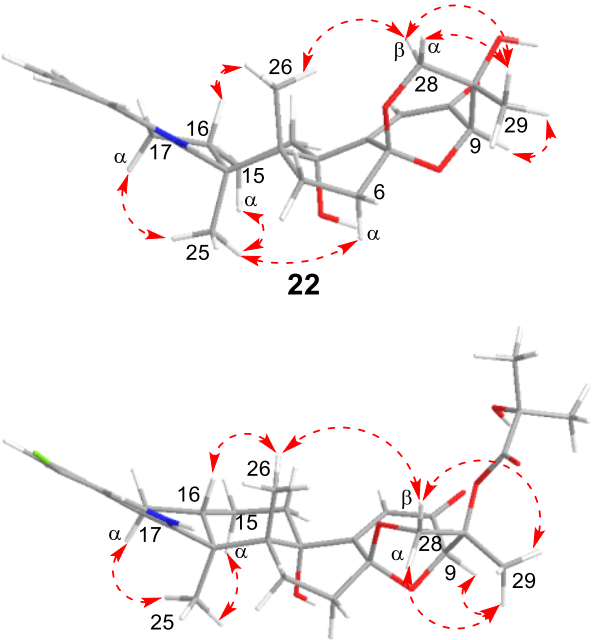

23
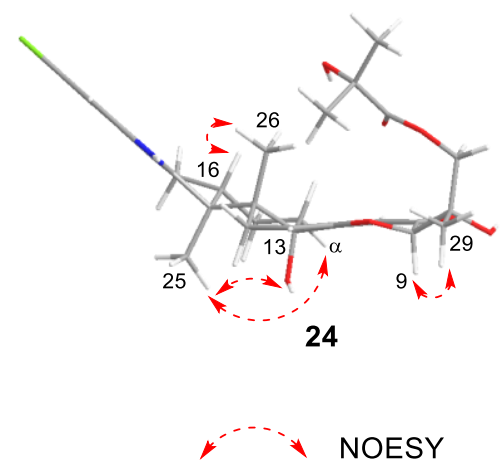

Figure 3. Selected COSY, HMBC, and NOESY correlations of compounds 22-24.

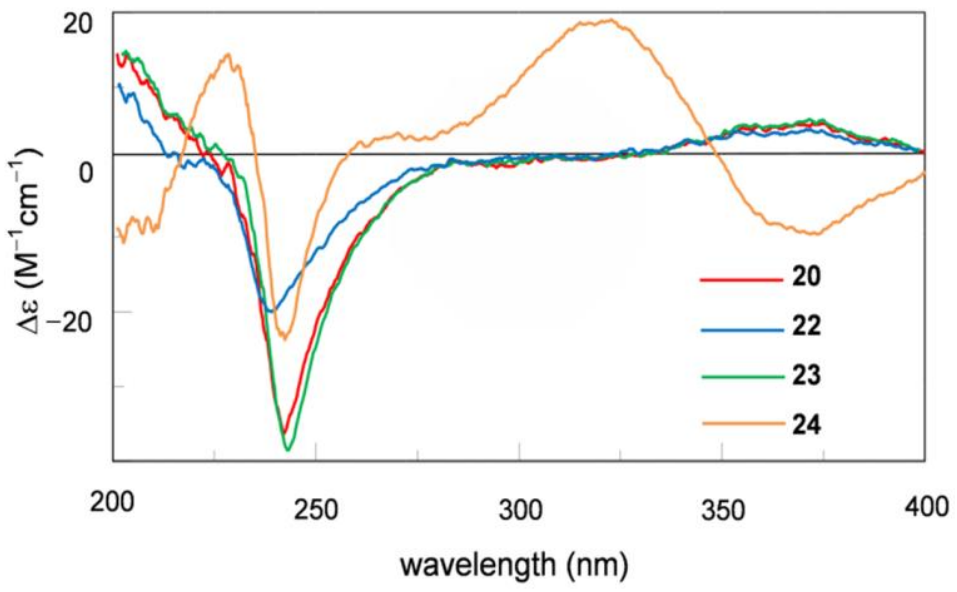

Figure 4. Experimental ECD data of compounds 20 and 22-24 in MeCN.

Asperindole G (24) was obtained as an optically active, white powder. Its HRESIMS gave the same molecular formula as that of asperindole $\mathrm{F}(23)$. As expected, the NMR data of 24 (Table 2) showed similarity to those of 23. However, two $s p^{3}$ carbon atoms ( $\delta$ 94.0, $\left.\mathrm{C} ; \delta 30.7, \mathrm{CH}_{2}\right)$ in 23 were replaced by two $s p^{2}$ carbon atoms $(\delta 145.0, \mathrm{C} ; \delta 111.5, \mathrm{CH})$ in 24, suggesting a cleavage of the ether bridge of ring $\mathrm{G}$ in 23 to form a C-6 to C-7 double bond, and a 28-hydroxymethyl group in 24 . The assignment for the C-6 to C-7 double bond was confirmed by the HMBC correlations of $\mathrm{H}-6$ with C-4 and C-12, and H-9 with C-7. In addition, the $\alpha$-hydroxyisobutyrate moiety was attached to the $\mathrm{C}$ - 28 methylene group of the side-chain instead of the C-27 of the bridged 1,3-dioxane ring (as those in 19-23), 
as confirmed by the diagnostic $\mathrm{HMBC}$ correlations between $\mathrm{H}_{2}-28$ and the ester carbonyl carbon $(\delta 175.5, \mathrm{C})$. Compound 24 was expected to have the same stereochemistry as that of 19-23 due to their obvious correlations in biogenetic origin, even though the ECD spectrum of $\mathbf{2 4}$ was significantly different from those of 20-23. However, a very weak NOE correlation was observed between $\mathrm{H}-9$ and $\mathrm{H}_{3}-26$ in the NOESY spectrum of 24 . This suggested that an epimerization might occur at C-9, which is adjacent to the C-10 ketone group. In order to determine the absolute configuration of C-9, TDDFT-ECD [33] and DFT-NMR calculations [34] were performed on the $(3 S, 4 R, 9 R, 13 S, 16 S, 27 S)$ and $(3 S, 4 R, 9 S, 13 S, 16 S, 27 S)$ epimers. Ring F, containing an $\alpha, \beta$-unsaturated carbonyl chromophore, was expected to have a major impact on the high-wavelength ECD transitions, and thus a large difference was expected between the ECD spectra of the two epimers. The initial Merck molecular force field (MMFF) conformational search resulted in 353 and 156 conformers in a $21 \mathrm{~kJ} / \mathrm{mol}$ energy window for $(3 S, 4 R, 9 R, 13 S, 16 S, 27 S)$-24 and $(3 S, 4 R, 9 S, 13 S, 16 S, 27 S)-24$, respectively. The re-optimization of these conformers yielded 15 and 17 low-energy conformers over the $1 \%$ Boltzmann distribution at the $\omega$ B97X/TZVP [35] PCM/MeCN level (Figures S83 and S84). Unexpectedly, the Boltzmann-weighted ECD spectra of both epimers computed at various levels reproduced well the major transitions of the experimental ECD spectrum, indicating that the contribution of ring $\mathrm{E}$ is dominant. However, the $(9 R)$ epimer could reproduce the $225 \mathrm{~nm}$ positive Cotton effect (CE) with a blue shift (Figure 5), while the (9S) epimer had only a negative computed CE below $250 \mathrm{~nm}$ (Figure 6). This small difference suggested that 24 had $(9 R)$ absolute configuration, and the difference in the experimental ECD spectra of 20-23 and $\mathbf{2 4}$ derives from the different chromophore systems and different planar structures. It is well-documented that even small structural changes can result in markedly different or mirror-image ECD spectra for homochiral derivatives by changing the preferred conformation or electronic properties of the molecule [36]. The $(9 R)$ and (9S) epimers were further distinguished by ${ }^{13} \mathrm{C}$ NMR DFT calculations, which has been proven an efficient method to distinguish diastereomeric natural products $[17,34]$. For the NMR calculations, the above MMFF conformers were re-optimized at the B3LYP/6-31 + $\mathrm{G}(\mathrm{d}, \mathrm{p})$ level yielding 16 and 14 low-energy structures above the $1 \%$ Boltzmann distribution, respectively. Despite the DMSO solvent and the presence of the halogen, both causing larger deviations in the computed data, the calculated ${ }^{13} \mathrm{C}$ NMR shifts of the (9R) epimer had a slightly smaller MAE average value than those of the (9S) epimer, and the DP4+ statistical analysis $[35,37]$ resulted in an $83.75 \%$ confidence for the $(9 R)$ epimer (Table S2). Since both the computed ECD and NMR data suggested ( $9 R$ ) configuration, the H-9 and $\mathrm{H}_{3}-26 \mathrm{NOE}$ cross-peak must be an artefact, and the absolute configuration of 24 was determined to be $(3 S, 4 R, 9 R, 13 S, 16 S, 27 S)$. The interatomic distance of $\mathrm{H}-9$ and $\mathrm{H}_{3}-26$ is 3.7 $\AA$ in the (9S) epimer and it is above $5.0 \AA$ in the (9R) epimer.

All the isolated compounds were evaluated for their neuronal modulatory activities by testing their effect on spontaneous $\mathrm{Ca}^{2+}$ oscillations (SCOs), and the seizurogenic agent 4-aminopyridine (4-AP) induced hyperexcitation in primary cultured neocortical neurons (Table 3). SCOs play a crucial role in mediating neuron development, and are closely associated with neuronal excitable and inhibitory neuronal transmission [38-40]. The compounds with modulatory activity on SCOs may have potential in drug candidates for treating neurological diseases such as epilepsy, pain and depression [41]. 


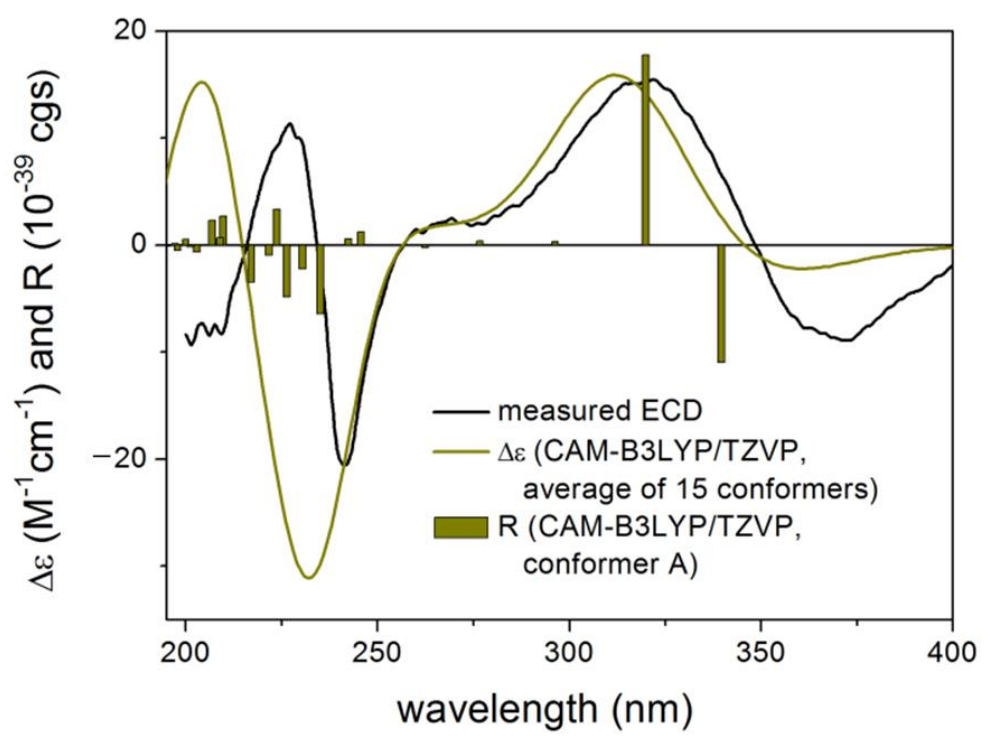

Figure 5. Experimental ECD spectrum of 24 in $\mathrm{MeCN}$ compared with the Boltzmann-weighted CAM-B3LYP/TZVP PCM/MeCN ECD spectrum of (3S,4R,9R,13S,16S,27S)-24. Level of optimization: $\omega \mathrm{B} 97 \mathrm{X} / \mathrm{TZVP} \mathrm{PCM} / \mathrm{MeCN}$. Bars represent the rotatory strength values of the lowest-energy conformer.

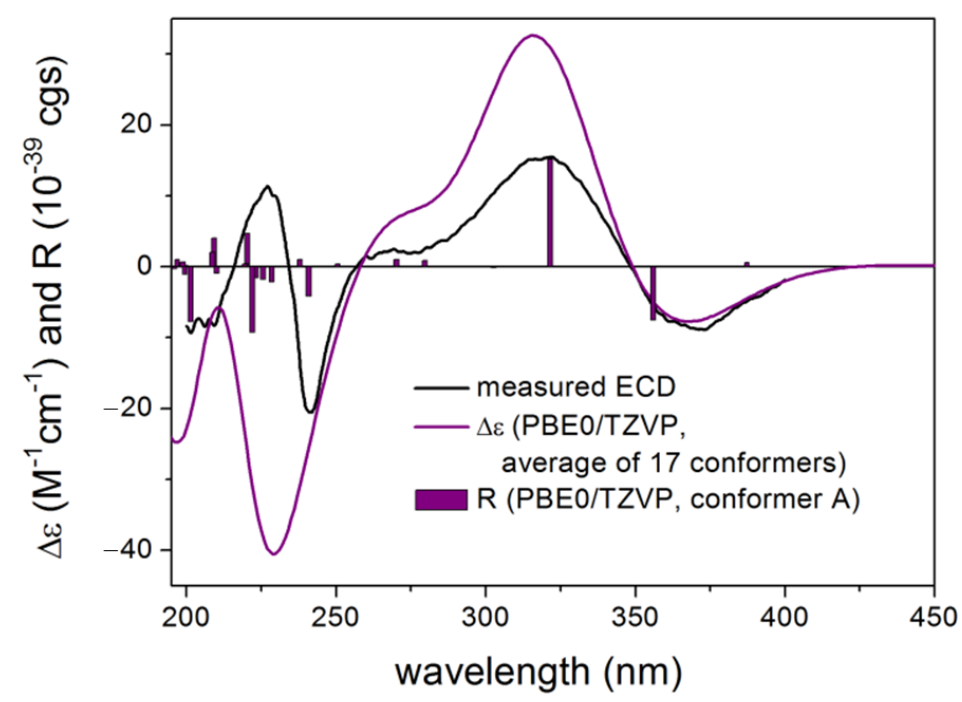

Figure 6. Experimental ECD spectrum of 24 in MeCN compared with the Boltzmann-weighted CAM-B3LYP/TZVP PCM/MeCN ECD spectrum of (3S,4R,9S,13S,16S,27S)-24. Level of optimization: $\omega \mathrm{B} 97 \mathrm{X} / \mathrm{TZVP} \mathrm{PCM} / \mathrm{MeCN}$. Bars represent the rotatory strength values of the lowest-energy conformer.

In the present study, we found that four compounds 6, 17, 18 and 24 inhibited SCO activity, and 4-AP induced hyperexcitability by decreasing the SCO amplitude and frequency in the primary cultured cortical neuronal network. However, compounds $\mathbf{9}$ and $\mathbf{1 4}$ produced a more complicated $\mathrm{Ca}^{2+}$ response. Their concentration dependently increased the SCO frequency with the concurrent suppression of the SCO amplitude at concentrations below $10 \mu \mathrm{M}$ and $3 \mu \mathrm{M}$, respectively, and transiently increased the intracellular $\mathrm{Ca}^{2+}$ concentration which recovered to basal level within $5 \mathrm{~min}$ at concentrations of $30 \mu \mathrm{M}$ and 10 $\mu \mathrm{M}$, respectively (Table 3, and Figures S85-S90). For the cluster of $p$-terphenyl derivatives, all the active compounds have hydroxyls for both $R_{2}$ and $R_{4}$ and those with hydrogens for both $R_{1}$ and $R_{3}$ displayed the strongest activity. Substitution for one of the $R_{2} / R_{4}$ pair of hydroxyls or one of the $R_{1} / R_{3}$ pair of hydrogens will decrease the activity. Interestingly, the degradation of ring A to a hydroxymethyl group may lead to an increase in activity. 
For the cluster of indole-diterpene alkaloids, ring cleavage on the ether bridge of ring $\mathrm{G}$ seems critical for the activity since all those compounds that have ring $\mathrm{G}$ are not active.

Table 3. Compounds influence SCOs and 4-AP-induced SCOs.

\begin{tabular}{ccccc}
\hline \multirow{2}{*}{ Compounds } & \multicolumn{2}{c}{ SCOs } & \multicolumn{2}{c}{$\begin{array}{c}\text { 4-AP-induced SCOs } \\
\text { EC }_{\mathbf{5 0}}(\boldsymbol{\mu} \mathbf{M}, \text { Mean } \pm \text { SEM) }\end{array}$} \\
\cline { 2 - 5 } & Amplitude & Frequency & Amplitude & Frequency \\
\hline 6 & $10.28 \pm 1.22$ & $6.96 \pm 0.73$ & $28.45 \pm 1.65$ & $27.08 \pm 2.94$ \\
17 & $3.86 \pm 0.06$ & $2.32 \pm 0.67$ & $3.70 \pm 2.11$ & $1.90 \pm 1.04$ \\
18 & $1.85 \pm 0.21$ & $2.68 \pm 0.04$ & $3.88 \pm 0.09$ & $3.67 \pm 0.01$ \\
24 & $5.62 \pm 1.39$ & $4.77 \pm 0.14$ & $6.05 \pm 0.83$ & $3.49 \pm 0.51$ \\
9 & $7.48 \pm 0.09$ & $5.32 \pm 3.92^{\mathrm{I}}$ & $\mathrm{N} / \mathrm{T}$ & $\mathrm{N} / \mathrm{T}$ \\
14 & $2.40 \pm 0.57$ & $0.26 \pm 0.08^{\mathrm{I}}$ & $\mathrm{N} / \mathrm{T}$ & $\mathrm{N} / \mathrm{T}$ \\
\hline
\end{tabular}

Data represent mean values of five independent experiments; “N/T" means not tested. "I" indicates increase in the SCO frequency.

\section{Experimental Section}

3.1. General Experimental Procedures

Optical rotations were determined with a Rudolph Autopol VI polarimeter. UV spectra were recorded on a Shimadzu UV-2700 spectrophotometer. IR spectra were recorded on a Bruker TENSOR II spectrophotometer. The ECD spectra were measured with a Jasco715 spectropolarimeter. NMR spectra were recorded on Bruker DRX-600 and DRX-500 spectrometers, and the signals of residual $\mathrm{CHCl}_{3}\left(\delta_{\mathrm{H}} 7.26 \mathrm{ppm} ; \delta_{\mathrm{C}} 77.0 \mathrm{ppm}\right), \mathrm{DMSO}\left(\delta_{\mathrm{H}}\right.$ $\left.2.50 \mathrm{ppm} ; \delta_{\mathrm{C}} 39.6 \mathrm{ppm}\right)$ and $\mathrm{CH}_{3} \mathrm{OH}\left(\delta_{\mathrm{H}} 3.31 \mathrm{ppm} ; \delta_{\mathrm{C}} 49.0 \mathrm{ppm}\right)$ were used as references for chemical shifts. The HR-ESI-MS data were recorded on an Agilent 1290-6545 UHPLC-QTOF-MS spectrometer. Semipreparative HPLC was performed using an Agilent Technology 1100 system with an ODS column (YMC Pack ODS-A, $10 \times 250 \mathrm{~mm}, 5 \mu \mathrm{M}$ ). Column chromatography (CC) was performed with Sephadex LH-20 gel (SE-751 84 Uppsala, GE Healthcare Bio-Sciences AB) and silica gel (200-300 mesh, 400-600 mesh; Yantai, China), respectively. The thin-layer chromatography (TLC) experiments were conducted with silica gel plates (HSGF-254, Yantai, China), and detected by heating after spraying with anisaldehyde sulfuric acid reagent.

\subsection{Fungal Material}

The fungal strain SG-8-(5) was isolated from the internal tissues of the gorgonian coral J. fragillis, which was collected from the Xisha area of the South China Sea, and identified as A. candidus by 18sRNA sequence (GenBank accession number AB008396.1). The fungus was deposited in Tongji University, Shanghai, China.

\subsection{Culture, Extraction and Isolation}

The fungal strain A. candidus was cultivated on $20.0 \mathrm{~L} \mathrm{of} 5 \% \mathrm{w} / \mathrm{v}$ biomalt (Villa Natura, Germany) solid agar medium $(20.0 \mathrm{~g} / \mathrm{L}$ biomalt, $15.0 \mathrm{~g} / \mathrm{L}$ agar, $800 \mathrm{~mL} / \mathrm{L}$ artificial seawater) at room temperature for 28 days. The fungal mycelia with the medium were extracted with EtOAc $(4.0 \mathrm{~L} \times 5)$ under ultrasonic conditions. The EtOAc extract was concentrated under vacuum (13.6 g) and was separated into thirteen fractions (Fr.1-13) by silica gel CC, eluting with a gradient $\mathrm{CH}_{2} \mathrm{Cl}_{2} / \mathrm{MeOH}$ (v/v 100:0 to 4:1). Fraction 2 (52.7 mg) was subjected to a Sephadex LH-20 CC $\left(\mathrm{CH}_{2} \mathrm{Cl}_{2} / \mathrm{MeOH} 2: 1\right)$ and then purified by HPLC $\left(\mathrm{MeOH} / \mathrm{H}_{2} \mathrm{O} 89: 11,1.5 \mathrm{~mL} / \mathrm{min}\right)$ to give $3\left(1.3 \mathrm{mg}, t_{\mathrm{R}} 18 \mathrm{~min}\right)$. Fraction $5(29.9 \mathrm{mg})$ was subjected to a Sephadex LH-20 CC $\left(\mathrm{CH}_{2} \mathrm{Cl}_{2} / \mathrm{MeOH} 2: 1\right)$ and HPLC $\left(\mathrm{MeOH} / \mathrm{H}_{2} \mathrm{O}\right.$ 80:20, $2.0 \mathrm{~mL} / \mathrm{min})$ to afford $5\left(3.1 \mathrm{mg}, t_{\mathrm{R}} 24 \mathrm{~min}\right)$. Fraction $6(644.9 \mathrm{mg})$ was subjected to a Sephadex LH-20 CC $\left(\mathrm{CH}_{2} \mathrm{Cl}_{2} / \mathrm{MeOH}\right.$ 2:1) to give eight subfractions (Fr.6a to Fr.6h). The Fr.6e $(215.8 \mathrm{mg})$ was separated by silica gel CC using a gradient petroleum (PE) in acetone (39:1 to 6:4), then split by HPLC to yield $7\left(1.2 \mathrm{mg}, \mathrm{MeOH} / \mathrm{H}_{2} \mathrm{O} 79: 21,1.5 \mathrm{~mL} / \mathrm{min}, t_{\mathrm{R}} 18\right.$ $\mathrm{min}), 8\left(0.9 \mathrm{mg}, \mathrm{MeOH} / \mathrm{H}_{2} \mathrm{O}\right.$ 79:21, $\left.1.5 \mathrm{~mL} / \mathrm{min}, t_{\mathrm{R}} 21 \mathrm{~min}\right), \mathbf{1}\left(1.2 \mathrm{mg}, \mathrm{MeOH} / \mathrm{H}_{2} \mathrm{O}\right.$ 80:20, 
$\left.2.0 \mathrm{~mL} / \mathrm{min}, t_{\mathrm{R}} 33 \mathrm{~min}\right), 19$ (1.8 mg, MeOH$\left./ \mathrm{H}_{2} \mathrm{O} 80: 20,2.0 \mathrm{~mL} / \mathrm{min}, t_{\mathrm{R}} 50 \mathrm{~min}\right), 20$ (2.3 mg, $\mathrm{MeOH} / \mathrm{H}_{2} \mathrm{O}$ 80:20, $\left.2.0 \mathrm{~mL} / \mathrm{min}, t_{\mathrm{R}} 63 \mathrm{~min}\right), 21$ (1.1 mg, $\mathrm{MeOH} / \mathrm{H}_{2} \mathrm{O} 80: 20,2.0 \mathrm{~mL} / \mathrm{min}, t_{\mathrm{R}}$ $36 \mathrm{~min}$ ). Fr.6f (54.7 mg) was separated by silica gel CC (PE-EtOAc 9:1 to 1:1) and purified by HPLC $\left(\mathrm{MeOH} / \mathrm{H}_{2} \mathrm{O} 80: 20,2.0 \mathrm{~mL} / \mathrm{min}\right)$ to afford $23\left(1.2 \mathrm{mg}, t_{\mathrm{R}} 44 \mathrm{~min}\right)$ and $24\left(0.7 \mathrm{mg}, t_{\mathrm{R}}\right.$ $25 \mathrm{~min})$. Fr.6g (18.7 mg) was purified by HPLC $\left(\mathrm{MeOH} / \mathrm{H}_{2} \mathrm{O} 70: 30,2.0 \mathrm{~mL} / \mathrm{min}\right)$ to afford $10\left(0.8 \mathrm{mg}, t_{\mathrm{R}} 23 \mathrm{~min}\right)$ and $22\left(0.9 \mathrm{mg}, t_{\mathrm{R}} 64 \mathrm{~min}\right)$. Fr.6h $(52.4 \mathrm{mg})$ was purified by HPLC $\left(\mathrm{MeOH} / \mathrm{H}_{2} \mathrm{O} 65: 35,2.0 \mathrm{~mL} / \mathrm{min}\right)$ to yield $16\left(1.6 \mathrm{mg}, t_{\mathrm{R}} 30 \mathrm{~min}\right), \mathbf{1 1}\left(1.5 \mathrm{mg}, t_{\mathrm{R}} 48 \mathrm{~min}\right)$, and $12\left(1.0 \mathrm{mg}, t_{\mathrm{R}} 51 \mathrm{~min}\right)$. Fraction $8(164.7 \mathrm{mg})$ was subjected to a Sephadex LH-20 CC $\left(\mathrm{CH}_{2} \mathrm{Cl}_{2} / \mathrm{MeOH} 2: 1\right)$ to yield thirteen subfractions (Fr.8a to Fr.8m). Fr.8h (19.8 mg) was further purified by HPLC (MeOH/ $\left.\mathrm{H}_{2} \mathrm{O} 70: 30,1.5 \mathrm{~mL} / \mathrm{min}\right)$ to afford $6\left(3.6 \mathrm{mg}, t_{\mathrm{R}} 13 \mathrm{~min}\right)$, $2\left(0.5 \mathrm{mg}, t_{\mathrm{R}} 20 \mathrm{~min}\right)$, and $15\left(3.1 \mathrm{mg}, t_{\mathrm{R}} 41 \mathrm{~min}\right) . \mathrm{Fr} .8 \mathrm{j}(33.4 \mathrm{mg})$ was purified by HPLC $\left(\mathrm{MeOH} / \mathrm{H}_{2} \mathrm{O} 65: 35,2.0 \mathrm{~mL} / \mathrm{min}\right)$ to afford 13 (13.9 mg, $\left.t_{\mathrm{R}} 18 \mathrm{~min}\right)$. Fraction 9 (364.2 mg) was subjected to a Sephadex LH-20 CC $\left(\mathrm{CH}_{2} \mathrm{Cl}_{2} / \mathrm{MeOH} 2: 1\right)$ to yield $4(50.0 \mathrm{mg})$. Fraction $10(649.6 \mathrm{mg})$ was subjected to a Sephadex LH-20 CC $\left(\mathrm{CH}_{2} \mathrm{Cl}_{2} / \mathrm{MeOH} 2: 1\right)$ to furnish fourteen subfractions (Fr.10a to Fr.10n) and pure compound 14 (11.6 mg). Fr.10g (29.3 mg) was further purified by HPLC $\left(\mathrm{MeOH} / \mathrm{H}_{2} \mathrm{O} 70: 30,2.0 \mathrm{~mL} / \mathrm{min}\right)$ to afford $18\left(2.0 \mathrm{mg}, t_{\mathrm{R}} 27.5\right.$ $\mathrm{min})$. Fr.10i $(84.5 \mathrm{mg}$ ) was separated by silica gel CC with the eluent of gradient petroleum ether-ethyl acetate from 9:1 to 1:1, followed by the purification of HPLC $\left(\mathrm{MeOH} / \mathrm{H}_{2} \mathrm{O}\right.$ $58: 42,2.0 \mathrm{~mL} / \mathrm{min})$ to yield $17\left(2.5 \mathrm{mg}, t_{\mathrm{R}} 42 \mathrm{~min}\right)$. Fraction $11(201.0 \mathrm{mg})$ was applied on a Sephadex LH-20 CC $\left(\mathrm{CH}_{2} \mathrm{Cl}_{2} / \mathrm{MeOH} 2: 1\right)$ and purified by HPLC $\left(\mathrm{MeOH} / \mathrm{H}_{2} \mathrm{O} 55: 45\right.$, $2.0 \mathrm{~mL} / \mathrm{min})$ to afford $9\left(13.0 \mathrm{mg}, t_{\mathrm{R}} 11 \mathrm{~min}\right)$.

The $4^{\prime \prime}$-O-methyl-prenylterphenyllin B (1): colorless, amorphous solid; UV (MeCN) $\lambda_{\max }(\log \varepsilon) 276$ (3.39), 248 (3.12), 209 (3.64) nm; IR (film) $v_{\max }$ 3357, 2922, 2852, 1659, 1609, $1462,1246,1073,1029,834,815 \mathrm{~cm}^{-1} ;{ }^{1} \mathrm{H}$ and ${ }^{13} \mathrm{C}$ NMR data see Table 1 ; HRESIMS $\mathrm{m} / \mathrm{z}$ $419.1870[\mathrm{M}-\mathrm{H}]^{-}$(calcd for $\left.\mathrm{C}_{26} \mathrm{H}_{27} \mathrm{O}_{5}, 419.1864\right)$.

The 3"-hydroxyl-prenylterphenyllin (2): colorless, amorphous solid; UV (MeCN) $\lambda_{\max }$ ( $\log \varepsilon) 277$ (3.28), 250 (3.13), 210 (3.65) nm; IR (film) $v_{\max }$ 3346, 2922, 2853, 1665, 1607, 1461, 1260, 1093, 799, $722 \mathrm{~cm}^{-1} ;{ }^{1} \mathrm{H}$ NMR $\left(\mathrm{CD}_{3} \mathrm{OD}, 500 \mathrm{MHz}\right): \delta_{\mathrm{H}} 7.11\left(1 \mathrm{H}, \mathrm{d}, J=2.2 \mathrm{~Hz}, \mathrm{H}-2^{\prime \prime}\right)$, $7.05(1 \mathrm{H}, \mathrm{d}, J=2.2 \mathrm{~Hz}, \mathrm{H}-2), 7.01(1 \mathrm{H}, \mathrm{dd}, J=8.2,2.2 \mathrm{~Hz}, \mathrm{H}-6), 6.96(1 \mathrm{H}, \mathrm{dd}, J=8.2,2.2 \mathrm{~Hz}$, H-6 $\left.6^{\prime \prime}\right), 6.83\left(1 \mathrm{H}, \mathrm{d}, J=8.2 \mathrm{~Hz}, \mathrm{H}-5^{\prime \prime}\right), 6.77(1 \mathrm{H}, \mathrm{d}, J=8.2 \mathrm{~Hz}, \mathrm{H}-5), 6.42\left(1 \mathrm{H}, \mathrm{s}, \mathrm{H}-5^{\prime}\right), 5.37(1 \mathrm{H}$, $\left.\mathrm{m}, \mathrm{H}-2^{\prime \prime \prime}\right), 3.67$ (3H, s, 6'-OMe), 3.41 (3H, s, 3'-OMe), $3.32\left(2 \mathrm{H}, \mathrm{m}, \mathrm{H}-1^{\prime \prime \prime}\right), 1.73\left(3 \mathrm{H}, \mathrm{s}, \mathrm{H}-5^{\prime \prime \prime}\right)$, $1.72\left(3 \mathrm{H}, \mathrm{s}, \mathrm{H}-4^{\prime \prime \prime}\right) ;{ }^{13} \mathrm{C}$ NMR $\left(\mathrm{CD}_{3} \mathrm{OD}, 125 \mathrm{MHz}\right): \delta_{\mathrm{C}} 154.8(\mathrm{C}, \mathrm{C}-4), 149.1\left(\mathrm{C}, \mathrm{C}-2^{\prime}\right), 146.1(\mathrm{C}$, C-3" $\left.{ }^{\prime \prime}\right), 145.9\left(\mathrm{C}, \mathrm{C}-4^{\prime \prime}\right), 140.8\left(\mathrm{C}, \mathrm{C}-3^{\prime}\right), 134.2\left(\mathrm{C}, \mathrm{C}-4^{\prime}\right), 133.2(\mathrm{CH}, \mathrm{C}-2), 132.7\left(\mathrm{C}, \mathrm{C}-3^{\prime \prime \prime}\right), 131.7$ $\left(\mathrm{C}, \mathrm{C}-1^{\prime \prime}\right), 130.3(\mathrm{CH}, \mathrm{C}-6), 128.2(\mathrm{C}, \mathrm{C}-3), 126.3(\mathrm{C}, \mathrm{C}-1), 124.2\left(\mathrm{CH}, \mathrm{C}-2^{\prime \prime \prime}\right), 121.5\left(\mathrm{CH}, \mathrm{C}-6^{\prime \prime}\right)$, $119.0\left(\mathrm{C}, \mathrm{C}-1^{\prime}\right), 117.2\left(\mathrm{CH}, \mathrm{C}-2^{\prime \prime}\right), 116.2\left(\mathrm{CH}, \mathrm{C}-5^{\prime \prime}\right), 115.1(\mathrm{CH}, \mathrm{C}-5), 105.0\left(\mathrm{CH}, \mathrm{C}-5^{\prime}\right), 60.8$ $\left(\mathrm{CH}_{3}, 3^{\prime}-\mathrm{OMe}\right), 56.5\left(\mathrm{CH}_{3}, 6^{\prime}-\mathrm{OMe}\right), 29.3\left(\mathrm{CH}_{2}, \mathrm{C}-1^{\prime \prime \prime}\right), 26.0\left(\mathrm{CH}_{3}, \mathrm{C}-5^{\prime \prime \prime}\right), 17.9\left(\mathrm{CH}_{3}, \mathrm{C}-4^{\prime \prime \prime}\right)$; HRESIMS $m / z 423.1787$ [M + H] $]^{+}$(calcd for $\mathrm{C}_{25} \mathrm{H}_{27} \mathrm{O}_{6}, 423.1802$ ).

The 3-methoxy-4"-deoxyterprenin (3): colorless, amorphous solid; UV (MeCN) $\lambda_{\max }$ ( $\log \varepsilon) 275$ (3.27), 250 (3.14), 202 (3.68); IR (film) $v_{\max }$ 3356, 2924, 2853, 1664, 1601, 1461, 1266, 1075, 829, $771 \mathrm{~cm}^{-1} ;{ }^{1} \mathrm{H}$ NMR $\left(\mathrm{CDCl}_{3}, 500 \mathrm{MHz}\right): \delta_{\mathrm{H}} 7.64\left(2 \mathrm{H}, \mathrm{dd}, J=7.5,1.5 \mathrm{~Hz}, \mathrm{H}-6^{\prime \prime}\right)$, $7.46\left(2 \mathrm{H}, \mathrm{td}, J=7.5,1.5 \mathrm{~Hz}, \mathrm{H}-5^{\prime \prime}\right), 7.39\left(1 \mathrm{H}, \mathrm{tt}, J=7.5,1.5 \mathrm{~Hz}, \mathrm{H}-4^{\prime \prime}\right), 7.02(1 \mathrm{H}, \mathrm{dd}, J=8.7$, $2.0 \mathrm{~Hz}, \mathrm{H}-6), 7.02(1 \mathrm{H}, \mathrm{d}, J=2 \mathrm{~Hz}, \mathrm{H}-2), 6.98(1 \mathrm{H}, \mathrm{d}, J=8.7 \mathrm{~Hz}, \mathrm{H}-5), 6.50\left(1 \mathrm{H}, \mathrm{s}, \mathrm{H}-5^{\prime}\right)$, $5.93\left(1 \mathrm{H}, \mathrm{s}, 2^{\prime}-\mathrm{OH}\right), 5.57\left(1 \mathrm{H}, \mathrm{m}, \mathrm{H}-2^{\prime \prime \prime}\right), 4.64\left(2 \mathrm{H}, \mathrm{d}, J=7 \mathrm{~Hz}, \mathrm{H}-1^{\prime \prime \prime}\right), 3.88$ (3H, s, 3-OMe), $3.76\left(3 \mathrm{H}, \mathrm{s}, 6^{\prime}-\mathrm{OMe}\right), 3.46\left(3 \mathrm{H}, \mathrm{s}, 3^{\prime}-\mathrm{OMe}\right), 1.79\left(3 \mathrm{H}, \mathrm{s}, \mathrm{H}-5^{\prime \prime \prime}\right), 1.75\left(3 \mathrm{H}, \mathrm{s}, \mathrm{H}-4^{\prime \prime \prime}\right) ;{ }^{13} \mathrm{C} \mathrm{NMR}$ $\left(\mathrm{CDCl}_{3}, 125 \mathrm{MHz}\right): \delta_{\mathrm{C}} 153.6\left(\mathrm{C}, \mathrm{C}-6^{\prime}\right), 149.1$ (C, C-3), 147.8 (C, C-4), $147.4\left(\mathrm{C}, \mathrm{C}-2^{\prime}\right), 139.0$ (C, C-3'), $138.2\left(\mathrm{C}, \mathrm{C}-1^{\prime \prime}\right), 137.6\left(\mathrm{C}, \mathrm{C}-3^{\prime \prime \prime}\right), 133.0\left(\mathrm{C}, \mathrm{C}-4^{\prime}\right), 128.9\left(\mathrm{CH}, \mathrm{C}-2^{\prime \prime}, 6^{\prime \prime}\right), 128.6(\mathrm{CH}$, $\left.\mathrm{C}-3^{\prime \prime}, 5^{\prime \prime}\right), 127.7\left(\mathrm{CH}, \mathrm{C}-4^{\prime \prime}\right), 125.4(\mathrm{C}, \mathrm{C}-1), 123.0(\mathrm{CH}, \mathrm{C}-6), 120.3\left(\mathrm{CH}, \mathrm{C}-2^{\prime \prime \prime}\right), 117.0\left(\mathrm{C}, \mathrm{C}-1^{\prime}\right)$, 114.4 (CH, C-2), $112.6(\mathrm{CH}, \mathrm{C}-5), 104.2\left(\mathrm{CH}, \mathrm{C}-5^{\prime}\right), 65.8\left(\mathrm{CH}_{2}, \mathrm{C}-1^{\prime \prime \prime}\right), 61.1\left(\mathrm{CH}_{3}, 3^{\prime}-\mathrm{OMe}\right)$, $56.2\left(\mathrm{CH}_{3}, 6^{\prime}-\mathrm{OMe}\right), 56.1\left(\mathrm{CH}_{3}, 3-\mathrm{OMe}\right), 26.0\left(\mathrm{CH}_{3}, \mathrm{C}-5^{\prime \prime \prime}\right), 18.4\left(\mathrm{CH}_{3}, \mathrm{C}-4^{\prime \prime \prime}\right) ; \mathrm{HRESIMS} \mathrm{m} / \mathrm{z}$ $421.2027[\mathrm{M}+\mathrm{H}]^{+}$(calcd for $\left.\mathrm{C}_{26} \mathrm{H}_{29} \mathrm{O}_{5}, 421.2010\right)$.

Phenylcandilide A (17): yellow, amorphous solid; UV (MeCN) $\lambda_{\max }(\log \varepsilon) 276$ (3.41), 256 (3.16), 242 (3.45), 227 (3.33), 209 (3.50), 203 (3.49) nm; IR (film) $v_{\max }$ 3359, 2922, 2852, $1658,1469,1266,1206,1091,831,738 \mathrm{~cm}^{-1} ;{ }^{1} \mathrm{H}$ and ${ }^{13} \mathrm{C}$ NMR data see Table 1 ; HRESIMS $m / z 337.1055[\mathrm{M}+\mathrm{Na}]^{+}$(calcd for $\left.\mathrm{C}_{18} \mathrm{H}_{18} \mathrm{NaO}_{5}, 337.1046\right)$. 
Phenylcandilide B (18): yellow, amorphous solid; UV (MeCN) $\lambda_{\max }(\log \varepsilon) 275$ (3.58), 255 (3.37), 240 (3.61), 227 (3.54), 212 (3.64) nm; IR (film) $v_{\max }$ 3354, 2924, 2853, 1740, 1660, 1497, 1267, 1213, 1172, 1104, 830, $671 \mathrm{~cm}^{-1} ;{ }^{1} \mathrm{H}$ and ${ }^{13} \mathrm{C}$ NMR data see Table 1; HRESIMS $m / z 357.1349[\mathrm{M}+\mathrm{H}]^{+}$(calcd for $\mathrm{C}_{20} \mathrm{H}_{21} \mathrm{O}_{6}, 357.1333$ ).

Asperindole E (22): white powder; $[\alpha]_{\mathrm{D}}^{20}+50.00\left(c\right.$ 0.03, $\left.\mathrm{CHCl}_{3}\right)$; UV $(\mathrm{MeCN}) \lambda_{\max }$ $(\log \varepsilon) 279$ (2.78), 268 (2.75), 230 (3.45), 210 (3.24) nm; ECD (0.045 mM, MeCN) $\lambda_{\max }(\Delta \varepsilon)$ 238 (-20.91) nm; IR (film) $v_{\max } 3360,2920,2851,1720,1658,1632,1468,1260,1016,800$, $742 \mathrm{~cm}^{-1} ;{ }^{1} \mathrm{H}$ and ${ }^{13} \mathrm{C}$ NMR data see Table 3; HRESIMS $m / z 472.2086[\mathrm{M}+\mathrm{Na}]^{+}$(calcd for $\left.\mathrm{C}_{27} \mathrm{H}_{31} \mathrm{NO}_{5} \mathrm{Na}, 472.2094\right)$.

Asperindole F (23): white powder; $[\alpha]_{\mathrm{D}}^{20}+40.56\left(c 0.03, \mathrm{CHCl}_{3}\right)$; UV $(\mathrm{MeCN}) \lambda_{\max }$ $(\log \varepsilon) 285$ (2.89), 267 (2.76), 236 (3.63), 209 (3.23) nm; ECD (0.035 mM, MeCN) $\lambda_{\max }(\Delta \varepsilon)$ $242(-39.92) \mathrm{nm}$; IR (film) $v_{\max } 3358,2920,2851,1730,1659,1633,1467,1260,1013,799$, $704 \mathrm{~cm}^{-1} ;{ }^{1} \mathrm{H}$ and ${ }^{13} \mathrm{C}$ NMR data see Table 3; HRESIMS $m / z 568.2120[\mathrm{M}-\mathrm{H}]^{-}$(calcd for $\left.\mathrm{C}_{31} \mathrm{H}_{35} \mathrm{ClNO}_{7}, 568.2108\right)$.

Asperindole G (24): white powder; $[\alpha]_{\mathrm{D}}^{20}+31.11\left(c 0.03, \mathrm{CHCl}_{3}\right) ; \mathrm{UV}(\mathrm{MeCN}) \lambda_{\max }(\log$ ع) 303 (2.92), 293 (2.90), 286 (2.91), 270 (2.85), 236 (3.56), 211 (3.33) nm; ECD (0.035 mM, $\mathrm{MeCN}), \lambda_{\max }(\Delta \varepsilon) 373$ (-8.91), 362 (-7.78), 322 (+15.46), 269 (+2.49), 241 (-20.56), 227 (+11.34) nm; IR (film) $v_{\max } 3349,2920,2851,1730,1659,1462,1260,1018,798 \mathrm{~cm}^{-1} ;{ }^{1} \mathrm{H}$ and ${ }^{13} \mathrm{C}$ NMR data see Table 3; HRESIMS $m / z$ 592.2068 [M + Na] ${ }^{+}$(calcd for $\mathrm{C}_{31} \mathrm{H}_{36} \mathrm{ClNO}_{7} \mathrm{Na}$, 592.2073).

\subsection{Neuronal Modulatory Activity Assay In Vitro}

The neuronal modulatory activities of 1-24 were evaluated by testing the effect on spontaneous $\mathrm{Ca}^{2+}$ oscillations (SCOs) and seizurogenic agent 4-aminopyridine (4-AP)induced hyperactive SCOs frequency and amplitude in primary cultured neocortical neurons as described previously [16,38]. Neocortical neurons at 9 days in vitro (DIV) were used to investigate the influence of tested compounds on intracellular $\mathrm{Ca}^{2+}$ concentration $\left(\left[\mathrm{Ca}^{2+}\right]_{i}\right)$. Briefly, the neurons were loaded with Fluo- 4 for $1 \mathrm{~h}$ at $37^{\circ} \mathrm{C}$ in Locke's buffer. After recording the baseline spontaneous $\mathrm{Ca}^{2+}$ oscillations for $5 \mathrm{~min}$, different concentrations of compounds were added to the corresponding well, and the $\left[\mathrm{Ca}^{2+}\right]_{i}$ was monitored for 15 min using FLIPR ${ }^{\text {tetra }}{ }^{\circledR}$. To test anti-epileptic potential of the meroterpenoids, 4-AP $(10 \mu \mathrm{M})$ was added and the monitoring for $\left[\mathrm{Ca}^{2+}\right]_{\mathrm{i}}$ was continued for an additional $10 \mathrm{~min}$. The presented data were values of $F / F_{0}$, where $F$ is the fluorescence intensity at any time point whereas $\mathrm{F}_{0}$ is the basal fluorescence. An event with $\Delta \mathrm{F} / \mathrm{F}_{0}$ over 0.1 unit was considered to be an SCO. The frequency and amplitude of SCOs were quantified using Origin software (V7.0) from a time period of $5 \mathrm{~min}$ after first or second addition of compound or vehicle (0.1\% DMSO).

\subsection{Computational Section}

Mixed torsional/low-frequency mode conformational searches were carried out by means of the Macromodel 10.8.011 software by using the Merck molecular force field (MMFF) with an implicit solvent model for $\mathrm{CHCl}_{3}$ [42]. Geometry re-optimizations were carried out at the B3LYP/6-31 + G(d,p) level in vacuo and the $\omega B$ 97X/TZVP level with the PCM solvent model for MeCN. TDDFT-ECD calculations were run with various functionals (B3LYP, BH\&HLYP, CAMB3LYP, and PBE0) and the TZVP basis was set as implemented in the Gaussian 09 package, with the same or no solvent model as in the preceding DFT optimization step [43]. ECD spectra were generated as sums of Gaussians with 3000 and $2700 \mathrm{~cm}^{-1}$ widths at half-height, using dipole-velocity-computed rotational strength values [44]. NMR calculations were performed at the mPW1PW91/6-311 + G(2d,p) level [45]. Computed NMR shift data were corrected with $\mathrm{I}=185.2853$ and $\mathrm{S}=-1.0306$ [46]. Boltzmann distributions were estimated from the B3LYP and $\omega$ B97X energies. The MOLEKEL software package was used for visualization of the results [47]. 


\section{Conclusions}

From the fungi A. candidus, associated with the South China Sea gorgonian Junceela fragillis, twenty-four metabolites having $p$-terphenyl and indole-diterpene frameworks were obtained with their structures and absolute configurations being elucidated on the basis of spectroscopic analysis and computational calculations. It was found that small structural changes can result in a markedly different ECD spectra, and ${ }^{13} \mathrm{C}$ NMR DFT calculations are an efficient method to distinguish diastereomeric natural products. Six compounds could modulate SCOs and 4 -aminopyridine hyperexcited neuronal activity in the in vitro biotest. A preliminary structureactivity relationship was discussed, which may give a reference for further investigation or chemical optimization of SCO modulators.

Supplementary Materials: The following are available online at https:/ /www.mdpi.com/article/ $10.3390 / \mathrm{md} 19050281 / \mathrm{s} 1$, tables for the experimental NMR data of 20 and computed NMR data of 24, figures for the 2D correlations of 1-3, MS, IR, UV, NMR spectra of 1-3, 17-18 and 22-24, the low energy conformers of the computed structures of 24 , and the in vitro effects of $6,9,14,17,18$ and 24 on SCOs.

Author Contributions: G.-Y.P. performed the experiments. T.K. and A.M. performed the quantum mechanical calculation. J.H. and Z.-Y.C. contributed to the bioassay. H.T. was responsible for the fungal isolation and fermentation. S.-C.M. and W.Z. conceived and designed the experiments. All authors have read and agreed to the published version of the manuscript.

Funding: This research was funded by the National Nature Science Foundation of China, grant numbers 81820108030 and 41806088. T.K and A.M. were supported by the National Research, Development and Innovation Office (K120181 and FK134653) and the János Bolyai Research Scholarship of the Hungarian Academy of Sciences.

Institutional Review Board Statement: The study was conducted according to the guidelines of the Declaration of Helsinki, and approved by the Institutional Review Board of China Pharmaceutical University (protocol code 2016-0011, approved at 2 March 2016).

Data Availability Statement: Data are contained within the article or Supplementary Materials.

Acknowledgments: The Governmental Information-Technology Development Agency (KIFÜ) is acknowledged for CPU time.

Conflicts of Interest: The authors declare no competing financial interest.

\section{References}

1. Klich, M.A. Biogeography of Aspergillus species in soil and litter. Mycologia 2002, 94, 21-27. [CrossRef]

2. Lin, Y.-K.; Xie, C.-L.; Xing, C.-P.; Wang, B.-Q.; Tian, X.-X.; Xia, J.-M.; Jia, L.-Y.; Pan, Y.-N.; Yang, X.-W. Cytotoxic $p$-terphenyls from the deep-sea-derived Aspergillus candidus. Nat. Prod. Res. 2019, 24, 1-5. [CrossRef]

3. Han, J.; Lu, F.; Bao, L.; Wang, H.; Chen, B.; Li, E.; Wang, Z.; Xie, L.; Guo, C.; Xue, Y.; et al. Terphenyl derivatives and terpenoids from a wheat-born mold Aspergillus candidus. J. Antibiot. 2020, 73, 189-193. [CrossRef]

4. Wei, H.; Inada, H.; Hayashi, A.; Higashimoto, K.; Pruksakorn, P.; Kamada, S.; Arai, M.; Ishida, S.; Kobayashi, M. Prenylterphenyllin and its dehydroxyl analogs, new cytotoxic substances from a marine-derived fungus Aspergillus candidus IF10. J. Antibiot. 2007, 60, 586-590. [CrossRef] [PubMed]

5. Buttachon, S.; Ramos, A.A.; Inácio, Â.; Dethoup, T.; Gales, L.; Lee, M.; Costa, P.M.; Silva, A.M.S.; Sekeroglu, N.; Rocha, E.; et al. Bis-indolyl benzenoids, hydroxypyrrolidine derivatives and other constituents from cultures of the marine sponge-associated fungus Aspergillus candidus KUFA0062. Mar. Drugs 2018, 16, 119. [CrossRef]

6. Shan, T.J.; Wang, Y.Y.; Wang, S.; Xie, Y.Y.; Cui, Z.H.; Wu, C.Y.; Sun, J.; Wang, J.; Mao, Z.L. A new p-terphenyl derivative from the insect-derived fungus Aspergillus candidus Bdf-2 and the synergistic effects of terphenyllin. PeerJ 2020, 8, 15. [CrossRef] [PubMed]

7. Ma, J.; Zhang, X.L.; Wang, Y.; Zheng, J.Y.; Wang, C.Y.; Shao, C.L. Aspergivones A and B, two new flavones isolated from a gorgonian-derived Aspergillus candidus fungus. Nat. Prod. Res. 2016, 31, 32-36. [CrossRef] [PubMed]

8. Zhou, G.; Chen, X.; Zhang, X.; Che, Q.; Zhang, G.; Zhu, T.; Gu, Q.; Li, D. Prenylated $p$-terphenyls from a mangrove endophytic fungus, Aspergillus candidus LDJ-5. J. Nat. Prod. 2020, 83, 8-13. [CrossRef]

9. Yan, W.; Li, S.J.; Guo, Z.K.; Zhang, W.J.; Wei, W.; Tan, R.X.; Jiao, R.H. New p-terphenyls from the endophytic fungus Aspergillus sp. YXf3. Med. Chem. Lett. 2017, 27, 51-54. [CrossRef]

10. Liu, S.S.; Zhao, B.B.; Lu, C.H.; Huang, J.J.; Shen, Y.M. Two new $p$-terphenyl derivatives from the marine fungal strain Aspergillus sp. AF119. Nat. Prod. Commun. 2012, 7, 1057-1062. [CrossRef] [PubMed] 
11. Cai, S.; Sun, S.; Zhou, H.; Kong, X.; Gu, Q. Prenylated polyhydroxy-p-terphenyls from Aspergillus taichungensis ZHN-7-07. J. Nat. Prod. 2011, 74, 1106-1110. [CrossRef] [PubMed]

12. Marchelli, R.; Vining, L.C. Terphenyllin, a novel p-terphenyl metabolite from Aspergillus Candidus. J. Antibiot. 1975, $28,328-331$. [CrossRef] [PubMed]

13. Munden, J.E.; Butterworth, D.; Hanscomb, G.; Verrall, M.S. Production of chlorflavonin, an antifungal metabolite of Aspergillus candidus. Appl. Microbiol. 1970, 19, 718-720. [CrossRef] [PubMed]

14. Kamigauchi, T.; Sakazaki, R.; Nagashima, K.; Kawamura, Y.; Yasuda, Y.; Matsushima, K.; Tani, H.; Takahashi, Y.; Ishii, K.; Suzuki, R.; et al. Terprenins, novel immunosuppressants produced by Aspergillus candidus. J. Antibiot. 1998, 51, 445-450. [CrossRef] [PubMed]

15. Liu, D.-H.; Sun, Y.-Z.; Kurtán, T.; Mándi, A.; Tang, H.; Li, J.; Su, L.; Zhuang, C.-L.; Liu, Z.-Y.; Zhang, W. Osteoclastogenesis regulation metabolites from the coral-associated fungus Pseudallescheria boydii TW-1024-3. J. Nat. Prod. 2019, 82, 1274-1282. [CrossRef]

16. Wang, H.-L.; Li, R.; Li, J.; He, J.; Cao, Z.-Y.; Kurtán, T.; Mándi, A.; Zheng, G.-L.; Zhang, W. Alternarin A, a drimane meroterpenoid, suppresses neuronal excitability from the coral-associated fungi Alternaria sp. ZH-15. Org. Lett. 2020, 22, 2995-2998. [CrossRef]

17. Sun, P.; Cai, F.Y.; Lauro, G.; Tang, H.; Su, L.; Wang, H.L.; Li, H.H.; Mándi, A.; Kurtán, T.; Riccio, R. Immunomodulatory biscembranoids and assignment of their relative and absolute configurations: Data set modulation in the density functional theory/nuclear magnetic resonance approach. J. Nat. Prod. 2019, 82, 1264-1273. [CrossRef]

18. Li, W.; Li, X.B.; Lou, H.X. Structural and biological diversity of natural p-terphenyls. J. Asian. Nat. Prod. Res. 2017, 20, 1-13. [CrossRef]

19. Liu, J.-K. Natural terphenyls: developments since 1877. Chem. Rev. 2006, 106, 2209-2223. [CrossRef]

20. Ivanets, E.V.; Yurchenko, A.N.; Smetanina, O.F.; Rasin, A.B.; Zhuravleva, O.I.; Pivkin, M.V.; Popov, R.S.; Von Amsberg, G.; Afiyatullov, S.S.; Dyshlovoy, S.A. Asperindoles A-D and a $p$-terphenyl derivative from the ascidian-derived fungus Aspergillus sp. KMM 4676. Mar. Drugs 2018, 16, 232. [CrossRef]

21. Tian, S.-Z.; Pu, X.; Luo, G.; Zhao, L.-X.; Xu, L.-H.; Li, W.-J.; Luo, Y. Isolation and characterization of new $p$-terphenyls with antifungal, antibacterial, and antioxidant activities from halophilic actinomycete Nocardiopsis gilva YIM 90087. J. Agric. Food. Chem. 2013, 61, 3006-3012. [CrossRef] [PubMed]

22. Liu, C.; Tagami, K.; Minami, A.; Matsumoto, T.; Oikawa, H. Reconstitution of biosynthetic machinery for the synthesis of the highly elaborated indole diterpene penitrem. Angew. Chem. Int. Ed. 2015, 54, 5529. [CrossRef]

23. Munday-Finch, S.C.; Wilkins, A.L.; Miles, C.O.; Tomoda, H.; Ōmura, S. Isolation and structure elucidation of lolilline, a possible biosynthetic precursor of the lolitrem family of tremorgenic mycotoxins. J. Agric. Food. Chem. 1997, 45, 199-204. [CrossRef]

24. Jiang, Y.; Ozaki, T.; Harada, M.; Miyasaka, T.; Sato, H.; Miyamoto, K.; Kanazawa, J.; Liu, C.; Maruyama, J.-I.; Adachi, M.; et al. Biosynthesis of indole diterpene lolitrems: Radical-induced cyclization of an epoxyalcohol affording a characteristic lolitremane skeleton. Angew. Chem. Int. Ed. 2020, 59, 17996-18002. [CrossRef] [PubMed]

25. Kawada, K.; Arimura, A.; Tsuri, T.; Fuji, M.; Komurasaki, T.; Yonezawa, S.; Kugimiya, A.; Haga, N.; Mitsumori, S.; Inagaki, M.; et al. Total synthesis of terprenin, a highly potent and novel immunoglobulin E antibody suppressant. Angew. Chem. Int. Ed. 1998, 37, 973-975. [CrossRef]

26. Enomoto, M.; Morita, A.; Kuwahara, S. Total synthesis of the tremorgenic indole diterpene paspalinine. Angew. Chem. Int. Ed. Engl. 2012, 51, 12833-12836. [CrossRef]

27. Li, J.; Tang, H.; Kurtán, T.; Mándi, A.; Zhuang, C.-L.; Su, L.; Zheng, G.-L.; Zhang, W. Swinhoeisterols from the south china sea sponge Theonella swinhoei. J. Nat. Prod. 2018, 81, 1645-1650. [CrossRef]

28. Kurobane, I.; Vining, L.C.; McInnes, A.G.; Smith, D.G. 3-Hydroxyterphenyllin, a new metabolite of Aspergillus candidus. Structure elucidation by $\mathrm{H}$ and $\mathrm{C}$ nuclear magnetic resonance spectroscopy. J. Antibiot. 1979, 32, 559-564. [CrossRef]

29. Belofsky, G.N.; Gloer, K.B.; Gloer, J.B.; Wicklow, D.T.; Dowd, P.F. New $p$-terphenyl and polyketide metabolites from the sclerotia of Penicillium raistrickii. J. Nat. Prod. 1998, 61, 1115-1119. [CrossRef]

30. Takahashi, C.; Yoshihira, K.; Natori, S.; Umeda, M. The structures of toxic metabolites of Aspergillus candidus. I. The compounds A and E, cytotoxic p-terphenyls. Chem. Pharm. Bull. 1976, 24, 613-620. [CrossRef]

31. Kobayashi, A.; Takemura, A.; Koshimizu, K.; Nagano, H.; Kawazu, K. Candidusin A and B: New p-terphenyls with cytotoxic effects on sea urchin embryos. Agric. Biol. Chem. 1982, 46, 585-589. [CrossRef]

32. Wang, W.; Liao, Y.; Tang, C.; Huang, X.; Luo, Z.; Chen, J.; Cai, P. Cytotoxic and antibacterial compounds from the coral-derived fungus Aspergillus tritici SP2-8-1. Mar. Drugs 2017, 15, 348. [CrossRef] [PubMed]

33. Mándi, A.; Kurtán, T. Applications of OR/ECD/VCD to the structure elucidation of natural products. Nat. Prod. Rep. 2019, 36, 889-918. [CrossRef] [PubMed]

34. Li, W.S.; Yan, R.J.; Yu, Y.; Shi, Z.; Mándi, A.; Shen, L.; Kurtán, T.; Wu, J. Determination of the absolute configuration of supercarbon-chain compounds by a combined chemical, spectroscopic, and computational approach: Gibbosols A and B. Angew. Chem. Int. Ed. 2020, 59, 13028-13036. [CrossRef] [PubMed]

35. Smith, S.G.; Goodman, J.M. Assigning stereochemistry to single diastereoisomers by GIAO NMR calculation: The DP4 probability. J. Am. Chem. Soc. 2010, 132, 12946-12959. [CrossRef] 
36. El-Kashef, D.H.; Daletos, G.; Plenker, M.; Hartmann, R.; Mándi, A.; Kurtán, T.; Weber, H.; Lin, W.; Ancheeva, E.; Proksch, P. Polyketides and a dihydroquinolone alkaloid from a marine-derived strain of the fungus Metarhizium marquandii. J. Nat. Prod. 2019, 82, 2460-2469. [CrossRef]

37. Grimblat, N.; Zanardi, M.M.; Sarotti, A.M. Beyond dp4: An improved probability for the stereochemical assignment of isomeric compounds using quantum chemical calculations of nmr shifts. J. Org. Chem. 2015, 80, 12526-12534. [CrossRef]

38. Cao, Z.; Cui, Y.; Nguyen, H.M.; Jenkins, D.P.; Wulff, H.; Pessah, I.N. Nanomolar bifenthrin alters synchronous Ca ${ }^{2+}$ oscillations $^{2}$ and cortical neuron development independent of sodium channel activity. Mol. Pharmacol. 2014, 85, 630-639. [CrossRef]

39. Zheng, J.; Chen, J.; Zou, X.; Zhao, F.; Guo, M.; Wang, H.; Zhang, T.; Zhang, C.; Feng, W.; Pessah, I.N.; et al. Saikosaponin d causes apoptotic death of cultured neocortical neurons by increasing membrane permeability and elevating intracellular $\mathrm{Ca}^{2+}$ concentration. Neurotoxicology 2019, 70, 112-121. [CrossRef]

40. Sinner, B.; Friedrich, O.; Zink, W.; Martin, E.; Fink, R.H.; Graf, B.M. Ketamine stereoselectively inhibits spontaneous Ca ${ }^{2+}$ oscillations in cultured hippocampal neurons. Anesth. Analg. 2005, 100, 1660-1666. [CrossRef]

41. Nathalie, P.; Ana, M.L.M.; Shapiro, M.S. New in vitro phenotypic assay for epilepsy: Fluorescent measurement of synchronized neuronal calcium oscillations. PLoS ONE 2014, 9, e84755.

42. MacroModel. Schrödinger LLC, 2015. Available online: http://www.schrodinger.com/macromodel (accessed on 17 March 2021).

43. Frisch, M.J.; Trucks, G.W.; Schlegel, H.B.; Scuseria, G.E.; Robb, M.A.; Cheeseman, J.R.; Scalmani, G.; Barone, V.; Mennucci, B.; Petersson, G.A.; et al. Gaussian 09; Revision E.01; Gaussian, Inc.: Wallingford, CT, USA, 2013.

44. Stephens, P.J.; Harada, N. ECD cotton effect approximated by the Gaussian curve and other methods. Chirality 2010, 22, 229-233. [CrossRef] [PubMed]

45. Adamo, C.; Barone, V. Exchange functionals with improved long-range behavior and adiabatic connection methods without adjustable parameters: The $m$ PW and $m$ PW1PW models. J. Chem. Phys. 1998, 108, 664-675. [CrossRef]

46. Pierens, G.K. ${ }^{1} \mathrm{H}$ and ${ }^{13} \mathrm{C}$ NMR scaling factors for the calculation of chemical shifts in commonly used solvents using density functional theory. J. Comput. Chem. 2014, 35, 1388-1394. [CrossRef]

47. Varetto, U. Molekel 5.4; Swiss National Supercomputing Centre: Manno, Switzerland, 2009. 